The influence of transformed government on citizen trust: insights from Bahrain

Mohamed Mahmood $^{\mathrm{a} *}$, Vishanth Weerakkody ${ }^{\mathrm{b}}$ and Weifeng Chen $^{\mathrm{a}}$

${ }^{a}$ Brunel Business School, Brunel University London, London, UK; ${ }^{b}$ Faculty of Management and Law, University of Bradford, Bradford, UK

*Correspondence author. Email: $\underline{\text { mohamed.mahmood@brunel.ac.uk }}$ 


\title{
The influence of transformed government on citizen trust: insights from Bahrain
}

\begin{abstract}
The trust and confidence of citizens in their governments has been declining in recent decades. Electronic government (e-government) is seen as a means to reverse this trend. Despite conflicting conclusions in the literature, there is a consensus that e-government-led transformation can improve citizen confidence and trust in government. This research investigates the influence of egovernment-led transformation on citizen trust and confidence in the context of a developing country, the Kingdom of Bahrain. A conceptual model is developed, tested and validated using an online survey targeting ordinary citizens of the country. Based on 313 responses, the findings suggest that citizen trust and confidence is positively influenced by a government transformation, and this relationship is mediated by both government performance and citizen satisfaction. In addition, the results show that key factors must be met to achieve transformed government through the use of e-government systems: transparency, accountability, and meeting citizens' expectations.
\end{abstract}

Keywords: trust and confidence; e-government; government; transformation; citizens

\section{Introduction}

The trust of citizens in their governments has declined in recent decades. The implementation of e-government systems as mediators between governments and citizens has been proposed as a means of reversing this trend (International Labour Organization, 2015; 2016; 2017; Morgeson, 2013; Morgeson \& Petrescu, 2011; Morgeson, VanAmburg, \& Mithas, 2011; Teo, Srivastava, \& Jiang, 2008; West, 2004). However, these efforts have not been successful (Bannister \& Connolly, 2011; Morgeson et al., 2011; Teo et al., 2008); although a number of advanced e-government platforms have been deployed around the world, citizens have been 
slow to adopt and participate in this form of administration (United Nations, 2014). Therefore, it has been posited that the adoption of e-government alone will not resolve the issue of declining citizen trust. Few studies have investigated this topic in-depth, and due to conflicting opinions and conclusions, this area remains poorly understood (see for example, Bannister \& Connolly, 2011; Hong, 2013; Morgeson et al., 2011; Teo et al., 2008; Tolbert \& Mossberger, 2006). Moreover, the number of studies investigating citizen trust and confidence in government as a dependent variable are limited and have not received proper attention (Morgeson et al., 2011; Tolbert \& Mossberger, 2006; Welch, Hinnant, \& Moon, 2005).

The introduction of e-government systems in the developing Gulf Corporation Council (GCC) countries in the early 2000s dramatically altered the way these governments interact with citizens. The new systems resulted in improved transparency, higher-quality services, cost savings, and increased effectiveness and efficiency of the member governments. As a developing region, GCC countries consider e-government implementation a strategic priority, and most countries in the region have achieved advanced stages of egovernment, including the provision of multi-channel access to public services for their citizens (e.g., mobile, kiosk, PC-based) (United Nations, 2012; 2014; 2016). Among members of the GCC, this study focuses on the Kingdom of Bahrain because it is a developing country and has the most advanced and mature e-government system in the Arab region. The advanced state of e-government systems in Bahrain and the limited number of studies in e-government both globally and within the GCC provide motivations for this study.

The literature on e-government in the GCC, particularly in Bahrain, has focused mainly on factors related to citizens' adoption of this type of service-delivery system (Weerakkody, El-Haddadeh, Al-Sobhi, Shareef, \& Dwivedi, 2013; Salmi \& Hasnan, 2016). No study of the GCC region has investigated citizen trust in government as a dependent 
variable along with other factors that also influence trust. Such investigations could provide important insights on how governments and citizens relate to each other. Although government transformation has been suggested to have the potential to reverse the present trend of declining citizen trust and confidence (Bannister \& Connolly, 2011; Waller \& Weerakkody, 2016), understanding how transformation is related to attitudes toward governments requires an understanding of the factors that can influence transformation.

Using the example of Bahrain, this research aims to identify the major factors that contribute to successful government transformation, determine how these factors influence government transformation, and determine whether government transformation can influence citizen trust and confidence. The relevance of this research lies in its contribution to the growing body of knowledge on e-government; government transformation; citizen behavior in terms of expectations, satisfaction, and trust and confidence in government; and government accountability and transparency. This research extends current relevant theories to include new linkages among the constructs proposed in the conceptual model. It also tests the applicability of these theories in Bahrain by confirming or denying these linkages. The outcomes of this research have implications for practical aspects of governance in developing countries like Bahrain that are undergoing rapid change. Government transformation can contribute to a country's wider socio-economic development. This is particularly important for Bahrain because its citizens' understanding of what happens in government and how government deals with its citizens has changed significantly in recent years, affecting citizen trust and confidence in the regime.

The rest of the paper is organized as follows. Section 2 provides a broad overview of the relevant literature along with the supporting theories. Section 3 presents the theories that support government transformation and citizen trust and confidence. A conceptual model and the relationships between the model constructs and the study hypotheses are presented in 
Section 4. Section 5 discusses the context of the research. The research methodology and the illustrative results of the major study conducted in Bahrain are outlined in Section 6. Section 7 outlines the practical and theoretical implications of the study as well as limitations and recommendations for future research. Section 8 presents the contributions, and Section 9 concludes.

\section{Factors affecting government transformation}

A range of factors affect citizens' experience of engagement with their governments, including the regime, political trust, citizen satisfaction, accountability, transparency, government performance, technology and associated aids, expectations and perceptions, and the manner in which governments transform over time. Public trust in both government and e-initiatives is declining. Morgeson et al. (2011) explored factors influencing the relationship of citizen trust in Congress in the US with the internet and e-government initiatives but failed to establish a significant correlation. Researchers elsewhere have reached different conclusions on the influence of e-government and government adoption of information and communication technology (ICT) on trust and confidence (Bannister \& Connolly, 2011; Hong, 2013; Teo et al., 2008; Tolbert \& Mossberger, 2006). In addition to improving relationships between citizens and government, e-government has been argued to lend credibility to policies through widespread public access (Bhuasiri, Zo, Lee, \& Ciganek, 2016; Rodríguez Bolívar, Alcaide Muñoz, \& López Hernández, 2016; Tolbert \& Mossberger, 2006). However, traditional government must adjust to the growing demand for transparency. To improve performance, e-government, technology, and citizen expectations must be linked together in a holistic manner (Bannister \& Connolly, 2011).

According to West (2004), e-government refers to the delivery of government-related information and services through the internet or other digital means. In addition to reversing 
the decline in citizen trust in government (Morgeson et al., 2011; Teo et al., 2008; Tolbert \& Mossberger, 2006), e-government is seen as a way to reflect transparency and accountability to meet society's needs and expectations by providing public services and facilitating effective communicative channels (Garcia-Murillo, 2013; Paroški, Konjović, Surla, \& Popović, 2015; Rodríguez Bolívar et al., 2016; Roztocki \& Weistroffer, 2016). The adoption of e-government by regimes around the globe has changed the way they provide public services.

Technology refers to information technology and its impact on business management (Al Rub, 2006). In the public sector, information technology platforms and associated systems and technologies enable departments to provide e-government services and be part of a transformed regime. By adopting information technologies within their operations, governments can fulfil their responsibility toward their citizens in a more effective, transparent manner (Garcia-Murillo, 2013; Hiller \& Bélanger, 2001).

Chen, Wei, and Chen (2003) define transparency as the ability of outsiders to assess a company's true position. In the context of this research, transparency is considered an important factor in the transformation and enhancement of government performance (Bannister \& Connolly, 2011; Garcia-Murillo, 2013). Song and Lee (2013) suggest that government transparency can be achieved through positive information propagations and releasing the details of government policies and programs. As expected, technology has improved communications between citizens and their governments, thus facilitating a transformational effect. The factors that influence citizen satisfaction with e-government include greater transparency, which can foster institutional- and process-based trust and confidence in government (Rodríguez Bolívar et al., 2016; Welch et al., 2005). Although citizens recognize that the information a government site provides is subjective and that its 
correctness and completeness cannot be independently confirmed, they are nevertheless more likely to trust a government and its services if they are aware of its activities.

Most definitions of accountability in the literature cite the provision of reasons and justifications for activities and actions by a service provider to its users (Huse, 2005; Institute of Social and Ethical Accountability, 1999; Roberts \& Scapens, 1985; Swift, 2001; Williams, 1987). Chen et al. (2003) define accountability as the responsibility of management to the organization's stakeholders. In the context of this paper, accountability refers to the readiness of a government department to provide justifications of its conduct to its citizens. A level of transformation is evident when e-government uses technology to produce efficient, effective, transparent, and accountable exchanges of information and transactions within a government and between a government and its citizens (Garcia-Murillo, 2013).

Parasuraman, Zeithaml, and Berry (1988) define expectations as what customers should be offered rather than what is available. Nam (2012) cites the gap between public expectations and perceptions as the most important contributor to the decline in public trust in government. As a result, improving public trust involves finding ways to bridge the information gap between public expectations and the services governments actually provide. Most governments now realize that they need to be forward-thinking, to properly manage and administer services, and to effectively engage with and empower their citizens. Therefore, technology is directed at increasing productivity and supporting citizen expectations. Innovative governments are creating ways to reach out to citizens and allow them to make their voices heard on the services they receive (Hanna, 2009).

The above factors play an important role in transforming governments from traditional to digital. In turn, this transition has the potential to influence the factors that contribute to government effectiveness and efficiency, improved quality of services, cost savings, socio-economic development, citizen satisfaction levels, and citizen trust and 
confidence. According to Bannister and Connolly (2011), transformation refers to changes in process, structure, lines of authority, locus, power, etc. Transformation is considered an independent variable that is expected to improve citizens' perceptions of government, as manifested in their trust and confidence (Morgeson et al., 2011).

Based on the above, three factors appear to be linked with government transformation: government performance, citizen satisfaction, and citizen trust and confidence in government. Hameed and Al-Shawabkha (2013) describe performance as an organization's ability to use existing resources in an effective and efficient manner to reach the highest levels of success and future progress. Morgeson et al. (2011) define satisfaction as the sum total of a citizen's sense of fulfilment with his or her experience. The dependent variable is trust and confidence in government. Trust refers to the level of confidence citizens have in their government to "do the right thing", and to act appropriately and honestly on behalf of the public' (Barnes \& Gill, 2000, p. 4). Confidence refers to citizens' experience with a specific agency and their confidence that the agency will do a good job delivering services in the future (Morgeson et al., 2011). The literature suggests that better government performance leads to satisfied citizens, which, in turn, has the potential to restore citizen trust and confidence in government (Garcia-Murillo, 2013; Van de Walle \& Bouckaert, 2003). Morgeson et al. (2011) also validate e-government's ability to transform public-sector service performance, democratic responsiveness, and citizen trust and confidence.

To summarize, the literature review reveals signs of a decline in citizen trust and confidence in government and a paucity of relevant in-depth research (Bannister \& Connolly, 2011; Hong, 2013; Morgeson et al., 2011; Teo et al., 2008; Tolbert \& Mossberger, 2006). This study aims to shed more light on the factors associated with citizen trust and confidence in government (Morgeson et al., 2011; Tolbert \& Mossberger, 2006). Broadly, trust and 
confidence seems to be influenced by government transformation. However, the factors that influence this transformation have not been adequately discussed, and appropriate theories have not been developed (Bannister \& Connolly, 2011; West, 2004). Accordingly, the findings of this research will be useful to governments and citizens, particularly those of developing countries like the Kingdom of Bahrain.

\section{Supporting theories}

A number of models and frameworks suggest that ICT-based government transformation yields socio-economic development (Alderete, 2017; Estevez \& Janowski, 2013; Meso, Musa, Straub, \& Mbarika, 2009; O’Donnell \& Turner, 2013; Palvia, Baqir, \& Nemati, 2017; Roztocki \& Weistroffer, 2016; Samoilenko \& Osei-Bryson, 2017). Indeed, the actual implementation of e-government and ICTs is generally considered a major influencer of socio-economic development (O’Donnell \& Turner, 2013; Paroški et al., 2015; Roztocki \& Weistroffer, 2016; Samoilenko \& Osei-Bryson, 2017; Zhao, Wallis, \& Singh, 2015). The United Nations' annual benchmarking studies of e-government identify how governments' online systems contribute to society in such ways as inclusion, digital literacy, and the development of better-informed citizens. The theories presented in this section are taken from the literature review. Table 1 summarizes the theoretical background presented in the discussions that follow.

\subsection{Dominant theory: exit-voice}

This research continues the work of Morgeson et al. (2011) by further investigating the concept of improving citizen trust and confidence in government through government transformation. Morgeson et al. (2011) propose a conceptual model based on theories related to the area of marketing that focuses on the formation of consumer attitudes (Bearden \& Teel, 
1983; Cadotte, Woodruff, \& Jenkins, 1987; Churchill \& Surprenant, 1982; Fornell, Johnson, Anderson, Cha, \& Bryant, 1996Parasuraman, Berry, \& Zeithaml, 1991). Several studies have adapted, applied and used these theories and models in relation to government and, specifically, to explore citizen attitudes toward the services governments provide (Donnelly, Wisniewski, Dalrymple, \& Curry, 1995; Fornell et al., 1996; Fornell, Mithas, \& Morgeson III, 2009a, 2009b; James, 2009; Van Ryzin, Muzzio, Immerwahr, Gulick \& Martinez, 2004). Morgeson et al.'s (2011) work on exit-voice theory is the core influencing model in the present research. Exit-voice theory states that when customers are satisfied, there are fewer complaints, and loyalty increases. Otherwise, customers have the option to exit (move to a competitor) or voice their complaints. Morgeson et al.'s (2011) model has been used to understand citizen trust and confidence in their government's adoption of e-government in terms of managing citizen expectations. Thus, this foundation is used here to build a model to investigate the influence of government transformation on citizen trust and confidence as measured by citizen perceptions of and satisfaction with government performance.

\subsection{The relationships of e-government and technology with transformation of government}

Since e-government and technology (or ICT) are related to each other, four key theories or types of theories are applicable to their relationships with transformation of government: EGOV $\rightarrow$ TRANSF and TECH $\rightarrow$ TRANSF.

The first is public administration theory. The transformation of government and governance to e-government and e-governance redefines key parts of public administration in terms of its core operations of public policy and the democratic nature of its supervision. Traditional processes are transformed into information-based ones (Zouridis \& Thaens, 2003). E-government initiatives for technology and government transformation require that 
different government entities to use ICT, including both hardware and software. Government entities can also use ICT for other purposes, such as to develop new policies that support both its citizens and the strategic processes of the entities. These initiatives will contribute to ICTenabled government transformation (Zouridis \& Thaens, 2003).

Structuration theory supports the introduction and use of technologies that facilitate interactions between governments and citizens (Orlikowski, 1992; Orlikowski, Yates, Okamura, \& Fujimoto, 1995; Orlikowski, 2000). Such technologies include those needed for the government's own purposes as well as e-government initiatives in public services; both alter existing structures and consequently bring about institutional transformation (Meijer, Koops, Pieterson, Overman, and Tije, 2012).

Theories related to user adoption represent the third category. As discussed above, the introduction of technologies for e-government and other purposes transforms the way governments manage their functions and deliver public services, i.e., institutional transformation. However, successful ICT-enabled government transformation requires clear, visible adoption of online government services by citizens, which can be explored through user-adoption theories such as the technology acceptance model (TAM) and diffusion of innovation (DOI) (Gilbert \& Balestrini, 2004).

Finally, several researchers have used institutional theory to conceptualize ICTenabled government transformation (Kim, Kim, \& Lee, 2009; Luna-Reyes \& Gil-García, 2011; Omar, Weerakkody, \& Sivarajah, 2017; Pina, Torres, \& Royo, 2009). Institutional theory encompasses three types of forces: coercive, mimetic and normative. In these studies, ICT, including e-government, is considered a formal institution that takes into account its relationships with the surrounding environment, organizational aspects, and stakeholders; communications with other government agencies; interactions with its citizens; and socioeconomic impacts on the country in general and the government system in particular. The 
applicability of institutional theory is based on a number of perspectives. The most important relates to the implementation of ICT, including e-government and the issues surrounding its implementation (Kim et al., 2009; Luna-Reyes \& Gil-García, 2011; Pina et al., 2009). In this context, institutional theory is often used alongside other theories, such as DOI (Pina et al., 2009). The technology-enactment framework of institutional theory has also been used along with dynamic simulation, particularly in system dynamics (Luna-Reyes \& Gil-García, 2011).

\subsection{The relationships of transparency and accountability with transformation of government}

Accountability is the natural result of adopting transparency, and both come with transformation (Bannister \& Connolly, 2011; Kim et al., 2009; Said, Iaafar, \& Atan, 2015). Three theories, including two discussed above, support the following relationships of transparency and accountability with transformation of government: TRANSPY $\rightarrow$ TRANSF and ACCOUNT $\rightarrow$ TRANSF.

According to public administration theory, in a transformed government, the adoption of ICT-supported transparency makes government-related information accessible to all stakeholders, including general citizens. This increased accessibility itself changes the way public administration works, acts and interacts; it also changes how citizens are given the freedom to appeal and voice their concerns if necessary.

In institutional theory, ICT-enabled government transformation results in enhanced transparency and accountability, which in turn affect its organizational aspects, institutional arrangements, and the way its institutions work and interact with stakeholders. Agentprincipal theory is also related to government accountability and transparency. Kim et al. (2009) use 'agent' to refer to government and 'principal' to refer to citizens. In this type of relationship, the principal (citizens) monitors and the agent (government) performs and 
reports on its progress using supporting evidence. The same principle applies to transformed government, which adopts transparency by, for example, making available to citizens the information that is necessary for all services, processes and procedures. Additionally, the agent (government) can share different reports, such as performance reports, KPIs achieved, and cases dealt with. As stated above, government accountability is achieved by default when such details are made available to citizens.

\subsection{The relationship between citizen expectations and transformation of government}

Stakeholder theory supports the relationship between citizen expectations and transformation of government, i.e., EXPEC $\rightarrow$ TRANSF. Stakeholder theory states that an organization that manages its relationships with its stakeholders effectively will perform well. If not, its performance will not be as good (Freeman, 2010). In stakeholder theory, 'relationship' refers to the interactions with stakeholders and the involvement of stakeholders in implementing and managing their own expectations. In the present context, citizen expectations of a truly transformed government should be managed, such as by introducing proper communication channels and a process of consultation on all aspects of government functions, activities, and services (Scott, Golden, \& Hughes, 2004).

\subsection{The relationship between transformation of government and government performance}

Public administration theory supports the relationship between transformation of government and government performance, i.e., TRANSF $\rightarrow$ PERFO. Here, the traditional government/public administration is transformed to an ICT-enabled government/public administration that integrates transparency and accountability into its work, functions and 
activities and manages citizen expectations. This transformation results in a modern government administration with improved government services and enhanced efficiency and effectiveness. Zouridis and Thaens (2003) note that the transformation of a government impacts the fundamental characteristics of its public administration and institutional structure.

\subsection{The relationships of citizen satisfaction with government performance and citizen trust and confidence in government}

Micro-performance theory supports the relationships of citizen satisfaction with government performance and citizen trust and confidence in government, i.e., PERFO $\rightarrow$ SATISF and SATISF $\rightarrow$ TRUST \& CONFIDENCE. This theory is simple and straightforward and considers trust in government as the ultimate outcome. Improved government performance increases citizen satisfaction and, in turn, citizen trust in government (Van de Walle \& Bouckaert, 2003). A number of prior studies have used micro-performance theory to understand the relationship between government performance and citizen trust and satisfaction (Kampen, Maddens, Vermunt, \& Salminen, 2003; Kampen, Van De Walle, \& Bouckaert, 2006; Van de Walle \& Bouckaert, 2003). These studies are useful guides when investigating the relationships among government transformation, citizen satisfaction, and citizen trust and confidence in government. In the context of this paper, a transformed government has the potential to increase the number of satisfied citizens, which, in turn, enhances citizen trust and confidence.

Although micro-performance theory supports this study's proposed conceptual model to some extent, it has not been used in the e-government or government-transformation literature. By contrast, exit-voice theory has been tested, validated, and used in the egovernment literature and is therefore considered the dominant theory supporting the proposed conceptual model. 


\section{[Table 1 near here]}

\section{Conceptual model and hypotheses}

\subsection{Conceptual model}

Researchers are still investigating the possible relationship between e-government and declining citizen trust in government, and thus the development of relevant models is in its early stages. For instance, Morgeson et al. (2011) investigated the relationship between the internet and citizen trust in Congress in the US as measured by e-government and influenced by other factors. However, the authors were unable to establish a significant relationship between citizen trust and government. Using trust in government as the independent rather than dependent variable, Teo et al. (2008) arrived at similar results when investigating the relationships between trust in government and e-government and between user satisfaction and intention to use e-government.

Based on the above arguments, it can be concluded that satisfaction and trust affect citizen engagement with government. Satisfaction is influenced by performance, which is in turn affected by a number of factors, including the technology used by the government, the use of e-government as a tool, and citizen expectations of government. Therefore, egovernment, technology, and expectations must be linked to transformation through changes in traditional government setup. However, without transparency and accountability, transformation is unlikely to improve performance (Bannister \& Connolly 2011). Consequently, transparency and accountability must be added to the use of e-government as a tool, the technology adopted by government departments, and citizen expectations as factors that influence transformation. Here, transformation is considered as an independent variable that is expected to increase citizen trust with government, which is the dependent variable. In addition, the relationship between these independent and dependent variables has been shown 
to be affected by mediating variables (Morgeson et al., 2011), including government performance and citizen satisfaction (Kim et al., 2009; Morgeson et al., 2011; Tolbert \& Mossberger, 2006; Welch et al., 2005; West, 2004). The supporting theories for the constructs and the relationships between these variables are explained in detail in Table 1.

The lack of understanding of how citizen engagement is influenced by government transformation constitutes an important gap in the literature. A better understanding of this relationship could be used to enhance citizen trust and confidence and consequently arrest the decline in citizen engagement with government.

In this context, this research attempts to expand the work of Morgeson et al. (2011) to further investigate the concept of citizen trust in a transformed government. Figure 1 outlines the proposed conceptual model for evaluating the influence of government transformation on citizen trust and confidence in Bahrain.

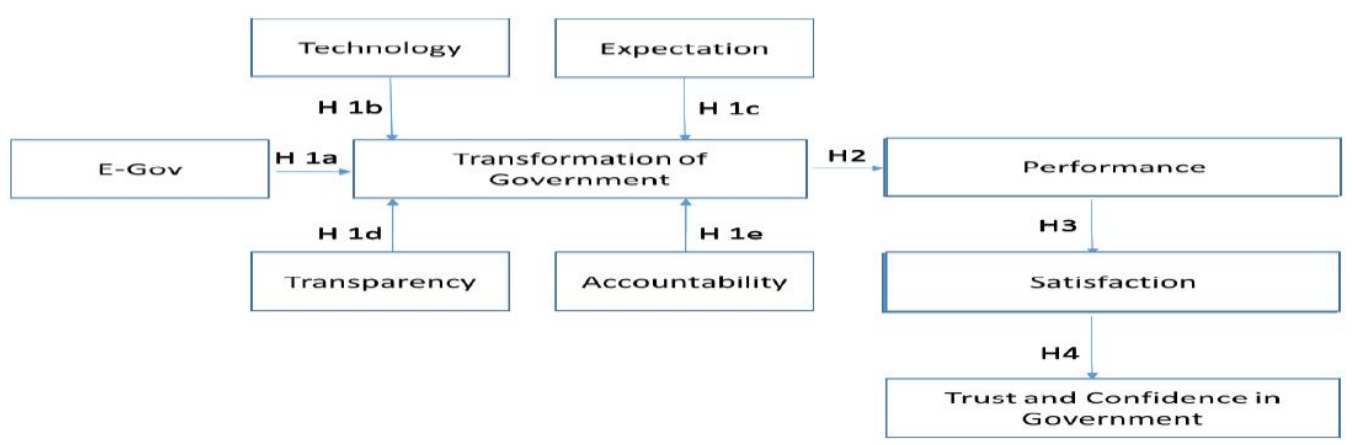

Figure 1. Conceptual model for evaluating the influence of government transformation on citizen trust and confidence.

This research adopts a citizen-centric perspective focused on the citizens' perceptions of the constructs and hypotheses of the conceptual model, such as how well the government performs; how technology is being implemented in government departments; the extent to which the government is practicing transparency and accountability; and so on for the remaining constructs. The same citizen-centric perspective applies to the suggested hypotheses. 


\subsection{The hypotheses}

In this research, two types of hypotheses are identified. The first is related to the influence of e-government, technology, expectations, transparency and accountability on transformation of government. The second is related to the role of mediators, as represented by government performance and citizen satisfaction, in the relationship between government transformation and citizen trust and confidence in government.

Based on the arguments presented earlier and the presented conceptual citizen-centric model, the following hypotheses are proposed:

H1a: E-government positively influences transformation of government.

H1b: Technology positively influences transformation of government.

H1c: Expectation positively influences transformation of government.

H1d: Transparency positively influences transformation of government.

H1e: Accountability positively influences transformation of government.

H2: Transformation of government positively influences government performance.

H3: Government performance positively influences citizen satisfaction with government.

H4: Satisfaction positively influences citizen trust and confidence in government.

\section{E-government-led transformation in Bahrain}

E-government initiatives in developing countries in the GCC have progressed greatly since their inception more than a decade ago. Government services are now continuously available online via different means, including e-government portals, mobile portals, e-kiosks, eservices centers, and national contact centers. Furthermore, the quality of services has been enhanced, thereby improving efficiency in human resources and reducing costs in government departments. 
Researchers have investigated e-government in GCC countries from a range of perspectives, including that of Bahrain. Most of these studies have addressed factors that influence the adoption and diffusion of e-government services (Salmi \& Hasnan, 2016; Weerakkody et al., 2013). For instance, trust was identified as a key factor in the adoption of e-government services (Al-Khouri, 2012). Cultural and social influences have also been identified as important factors (Al-Sobhi, Weerakkody, \& Kamal, 2010; Carter \& Weerakkody, 2008; Khalil, 2011). Rodrigues, Sarabdeen, and Balasubramanian (2016) suggest that confidentiality, trust, and attitudes toward using technology are major factors for e-government adoption in the UAE. In Saudi Arabia, confidentiality, privacy, and security were identified as important factors for the successful implementation of e-government services (Yamin \& Mattar, 2016); in addition to these factors, responsiveness, efficiency, and reliability were determined to be major factors in determining the quality of e-government (Sharma, Govindaluri, \& Gattoufi, 2015). However, no study in the GCC has used trust as a dependent factor or assessed the impact of government transformation on citizen trust and confidence.

The notable efforts in e-government by GCC countries have been recognized by the international community and, specifically, the e-Government Development Index (EGDI) of the United Nations, which consists of three sub-indicators: the Global Government Index, Online Service Index, and E-Participation Index. Table 2 shows the global rankings of GCC countries in the EGDI for selected years between 2005 and 2016 (United Nations, 2016).

[Table 2 near here]

The government of the Kingdom of Bahrain is committed to transformation through ICT, as evidenced by the establishment of the E-Government Authority, now the Information and E-Government Authority (iGA), in 2007. Bahrain is a leader in e-government at the 
GCC, Arab, Asian, and global levels, as confirmed by the United Nations in its United Nations E-Government Survey issued in 2010, 2012, 2014, and 2016. In addition, Bahrain's e-government initiatives have received more than 30 international awards. Bahrain was the first country in the Arab region to be classified as a "very high-performing country in EGDI", placing it among the most advanced countries in the world (United Nations, 2014). In the most recent United Nations report, UAE joined Bahrain in this category (United Nations, 2016).

E-government initiatives in Bahrain have resulted in a transformed government, improved citizen interaction and engagement with government, higher-quality services, cost savings, socio-economic benefits, and satisfied citizens. According to data released by the iGA in June 2016, more than 300 e-government services are provided to citizens through different means. In 2016, the e-government portal received a total of 782,221 visits; 468,892 people used its services; 59,658 transactions were made, and BD 3,355,021 in fees were collected. Mobile services were used by 754,201 people; 4,379 transactions were made, and BD 231,306 was collected. Kiosk devices were used by 4,761 people, 744 transactions were made, and BD 6,871 was collected. These statistics show that e-government in Bahrain has reached an advanced stage and helps facilitate government transformation.

Despite this progress, between 2014 and 2016, Bahrain's rankings in the EGDI Index and E-Participation sub-index decreased by 6 and 18 positions, respectively (United Nations, 2014; 2016). E-participation has been identified as a key challenge in both developed and developing countries (United Nations, 2014; 2016). The declines in Bahrain's rankings may be related to the decline in citizen trust and confidence in government (Al-Sobhi, Weerakkody, \& Kamal, 2010). In particular, the International Labour Organization (ILO) has highlighted a rapid decline in citizen trust, causing alarm in the GCC region in general and Bahrain in particular (International Labour Organization, 2015; 2016; 2017). 
Given the aim and objectives of this research, Bahrain is a good candidate for investigating how government transformation influences citizen trust and confidence and identifying the major factors that contribute to successful government transformation.

\section{Methodology and data analysis}

The systematic literature review, including the examination of the GCC and Bahrain, provided a foundation for the development of a conceptual model and hypotheses for the relationships of e-government, government transformation, and accountability with citizen trust and confidence in government. After testing its validity and reliability, the conceptual model was used to test the hypotheses (Wood \& Welch, 2010). Since the target in this research is ordinary citizens of the Kingdom of Bahrain, a quantitative research method was used to test the conceptual model to ensure that it accurately represented the population, in line with methods used in similar research (e.g., Morgeson et al., 2011; Teo et al., 2008; Tolbert \& Mossberger, 2006). As e-government is at an advanced stage in Bahrain and the majority of citizens use it to conduct their transactions with the regime, the sampling technique consisted of an online survey and random sampling of ordinary citizens. This enabled the collection of data from a large number of people from different backgrounds using a sampling technique in line with those used in similar studies in the field (Weerakkody et al., 2013). Moreover, since the subject of this research is related to citizen trust and confidence in government, which is politically sensitive at present in Bahrain, the online survey was developed based on a seven-point Likert-type scale to increase the number of choices and to avoid, as much as possible, the selection of 'neutral' choices. 


\subsection{Data collection methods}

The survey questionnaire followed the technique used in the reviewed literature (Table 3). Appendix 1 presents the measurement items for each construct of the proposed model. The design of the questionnaire was checked by two academics and two experts/practitioners in egovernment. To evaluate feasibility, predict the appropriate sample size, and improve the research design, a pilot survey comprising 55 questions was used before the full-scale launch of the survey. The pilot survey was posted on a web portal, and a URL was sent to ordinary citizens via social-networking applications (i.e., WhatsApp and Facebook, SMS, LinkedIn) and email. The pilot study was conducted in September 2015, and the analysis was completed in early October 2015.

[Table 3 near here]

Based on the outcomes of the pilot study, the main survey of 51 questions (as shown in Appendix 2) was conducted between October 2015 and November 2015. The survey was communicated to the public via social-networking applications (i.e., WhatsApp and Facebook, SMS, LinkedIn) and email and reached approximately 1000 people. The total number of responses was 513 , corresponding to a response rate of approximately $51 \%$, which is considered good in information-system research (Fowler, 2002). However, only 313 responses were properly completed; the rest included only demographic details and left many questions unanswered. These 200 incomplete responses were discarded. The sample size of 313 is considered adequate as per Tabachnick, Fidell and Osterlind (2001) and Comrey and Lee (1992).

The profile of the respondents is shown in Table 4; no significant bias in gender or age was observed. However, many of the respondents were highly educated and well-paid. 
Question 7 (Q7) was eliminated as it did not pass the validity test using SPSS, and thus the sample size had no impact on the outcomes of the testing. The target audience may not have properly understood this question.

\subsection{Confirmatory factor analysis}

Confirmatory factor analysis (CFA) was performed to test the validity of the constructs. Questions 8, 9, and 10 (Q8, Q9 and Q10) did not pass the validity test and were therefore excluded from the analysis.

CFA indicated a good fit $($ Chi-Square $($ CMIN) $=1997.084$; degrees of freedom $(D F)$ $=991 ; \mathrm{CMIN} / \mathrm{DF}=2.015 ; \mathrm{CFI}=.923 ; \mathrm{RMSEA}=.057)$. As shown in Table 5, the composite reliability (CR) of all constructs was higher than 0.7 (Nunnally \& Bernstein, 1994), suggesting an adequate level of reliability. In terms of convergent validity, the average variance extracted (AVE) was above 0.5 for all constructs (Fornell \& Larcker, 1981). These results all suggest good validity of the measurement model.

\section{[Table 5 near here]}

Table 6 presents the correlation matrix, mean, and standard deviation of the constructs in the proposed model.

[Table 6 near here]

\subsection{Research hypothesis test results}

The path analysis results indicated that the eight hypotheses developed for this research were supported (Table 7).

[Table 7 near here] 


\subsection{Mediation effects}

Two mediators play an important role in the relationship between transformation of government and citizen trust and confidence: government performance and citizen satisfaction. As illustrated in Appendix 3, the paths between SATISF $\rightarrow$ TRU_COF, $\mathrm{PERFO} \rightarrow \mathrm{TRU}$ _COF and TRANSF $\rightarrow$ TRU_COF were all significant, suggesting that both performance and satisfaction partially mediate the relationship between transformation of government and citizen trust and confidence. Figures 2 to 5 illustrate the direct and indirect effects of all of the paths in the proposed conceptual model; all paths are significant.

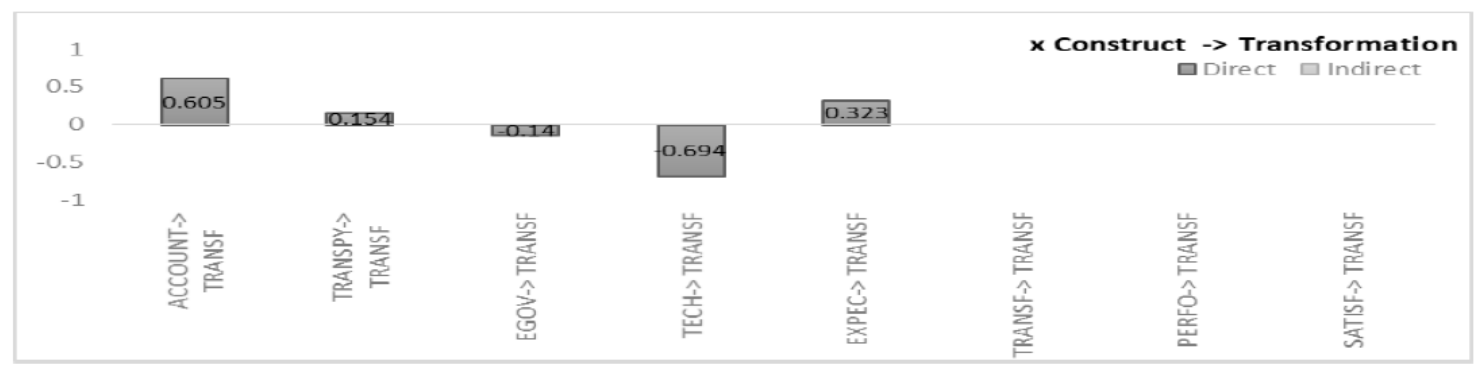

Figure 2. Total effects of the direct and indirect paths on transformation.

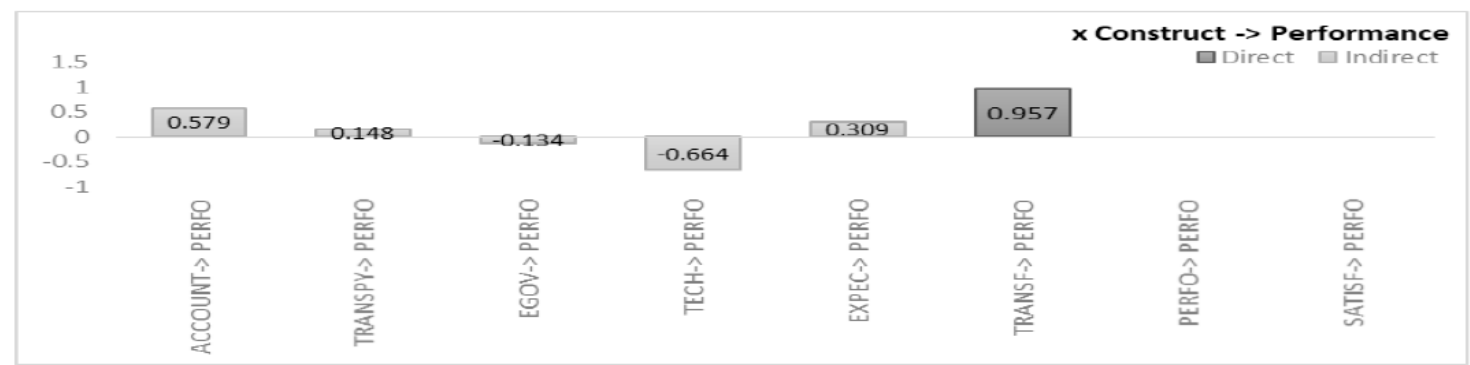

Figure 3. Total effects of the direct and indirect paths on performance. 


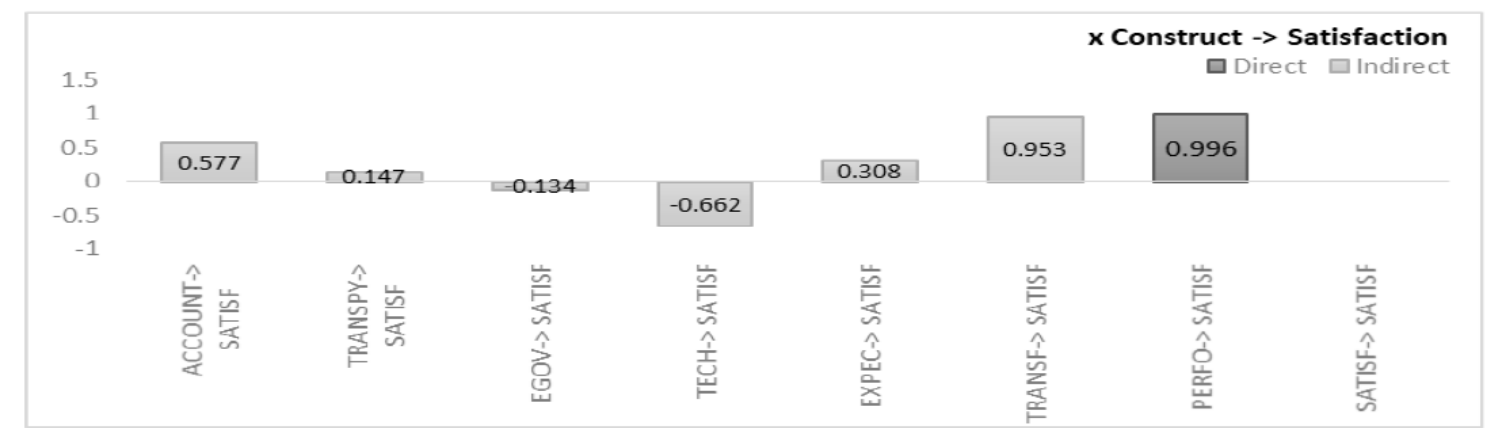

Figure 4. Total effects of the direct and indirect paths on satisfaction.

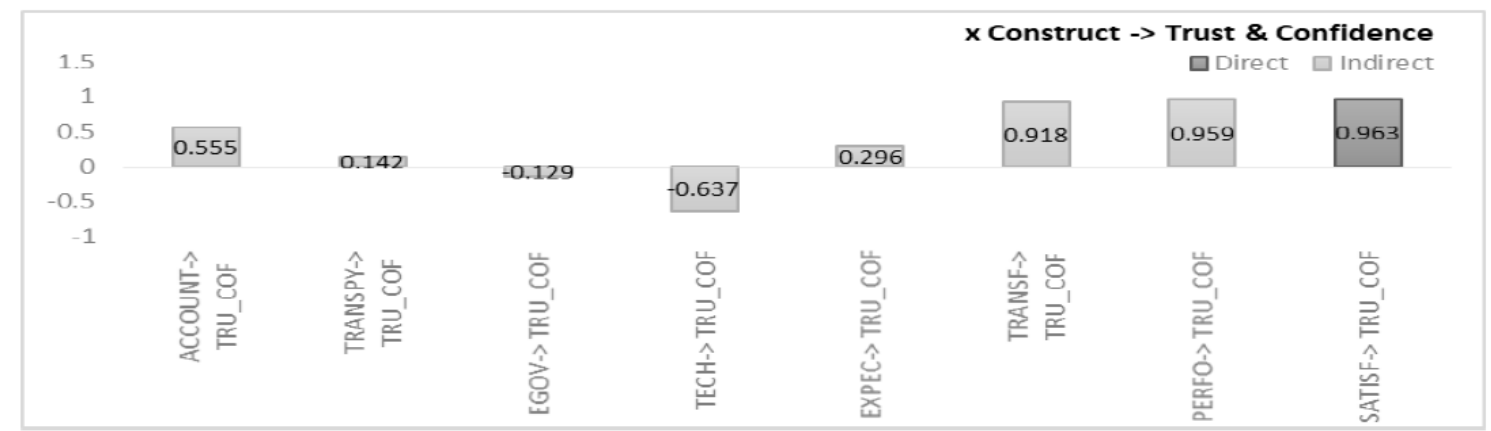

Figure 5. Total effects of the direct and indirect paths on trust and confidence.

\section{Discussion}

\subsection{Summary of the results}

The results of this research reveal that five factors influence the transformation of government in Bahrain: (i) e-government; (ii) the technology used by government agencies; (iii) citizen expectations; (iv) government transparency; and (v) the accountability of government agencies to citizens. Three factors positively influence transformation of government: (i) citizen expectations; (ii) transparency; and (iii) accountability. Two factors negatively influence transformation of government: (i) e-government and (ii) technology.

Transformation of government positively influences citizen trust and confidence as mediated by government performance and citizen satisfaction. The relationships between transformation of government and government performance, government performance and 
citizen satisfaction, and citizen satisfaction and citizen trust and confidence are all positive. Moreover, both performance and satisfaction partially mediate the relationship between transformation and trust and confidence in government.

Of particular interest, e-government, technology, transparency, accountability, and citizens' expectations have significant indirect relationships with citizen trust and confidence. These five factors also have significant indirect relationships with government performance and citizen satisfaction.

All of these findings are supported by the literature, including the two negative relationships between e-government and government transformation and between technology and government transformation. Specifically, the literature shows that e-government was introduced as a solution to transform governments and reverse the decline in citizen trust and confidence but has not achieved these objectives (Bannister \& Connolly, 2011; Gunawong \& Gao, 2017; Miyata, 2011; Morgeson et al., 2011; Rodríguez Bolívar et al., 2016). Although previous research on the influence of e-government on trust in governments has yielded conflicting conclusions, these studies have revealed that technology in general and egovernment in particular do not work alone and that not all relevant factors were considered in most cases of e-government implementation. No real government transformation was achieved because the focus of implementation was on technical solutions for government services, such as websites, portals, mobile services, and kiosks, rather than the core functions of governments, which include developing and implementing policies and administering legal and regulatory instruments (Bannister \& Connolly, 2011; Waller \& Weerakkody, 2016).

\subsection{Theoretical contribution}

This study enriches the literature on the influence of transformation of government on citizen trust and confidence in government, the information-system literature in general, and the e- 
government literature in particular. Previous studies have not sufficiently discussed the factors that affect government transformation. By considering all perspectives, this study confirms that e-government alone cannot transform governments and enhance citizen trust and confidence. The mediating roles of government performance and citizen satisfaction in the link between government transformation and citizen trust and confidence are also confirmed. This research therefore contributes to the growing body of knowledge on the important concepts of e-government; government transformation; citizen behavior in terms of expectations, satisfaction, and trust and confidence in government; and government accountability and transparency.

This study is the first to propose a conceptual framework to investigate the relationship between government transformation and citizen trust and confidence. Previous theoretical models and frameworks have mainly focused on the influence of trust in government and the adoption of e-government systems (Abu-Shanab \& Al-Azzam, 2012; Bélanger \& Carter, 2008; Carter \& Bélanger, 2005; Teo et al., 2008) and on the relationship between e-government and trust in government (Grimmelikhuijsen, 2009; McNeal, Hale, \& Dotterweich, 2008; Morgeson et al., 2011; Pina et al., 2009; Tolbert \& Mossberger, 2006). The single study covering the elements of government transformation and trust in government utilized an e-government perspective rather than an e-government-led 'government-transformation' perspective (Welch et al., 2005). The present research extends currently applicable theories to new linkages among the constructs proposed in the conceptual model, which was tested and verified for Bahrain, a developing country.

Based on the above, this study enriches the literature on citizen trust in several ways. First, it utilizes a technical approach to investigate citizen trust in government and the effects of e-government-led transformation on citizen trust and confidence. Second, this research provides knowledge on how citizen trust and confidence decline and the factors that 
contribute to this decline. This knowledge was acquired by reviewing the current literature and by building a conceptual model and testing it in the context of Bahrain. The findings of this research are therefore specifically relevant to developing counties.

\subsection{Practical implications}

E-government initiatives alone will not result in real transformed government; other important factors must be considered, including the instruments used to implement and deliver new policies and the role of ICT in this context (Waller \& Weerakkody, 2016). Achieving improved governance, increased trust, improved citizen satisfaction, enhanced efficiency and effectiveness, reduced corruption, lower costs, and high-quality services requires that governments adopt a balanced approach in positioning e-government to transform public institutions.

Digitally enabled government transformation is an important element of the socioeconomic development of any country. True government transformation contributes to the socio-economic development of all sectors, thereby maximizing benefits to citizens and the country as a whole. For instance, Zhao et al. (2015) show that there is a strong reciprocal relationship between digitally enabled government and the digital economy, which refers not only to a country's economy but also to its entire society. This socio-economic development is evident in innovative business models, how people interact and communicate, the transformation of government policies and practices, and economic growth (Ashaye \& Irani, 2014; Paroški et al., 2015; Roztocki \& Weistroffer, 2016; Samoilenko \& Osei-Bryson, 2017; Zhao et al., 2015). Ashaye and Irani (2014) argue that digitally enabled government transformation is a means to transform what a government does and highlight a number of interesting socio-economic benefits, such as counterbalancing political instability, improving 
culture, enhancing revenue collection for government, and promoting the issuance of simplified legal instruments and regulations.

The digital transformation of government also contributes to a country's wider socioeconomic development by fostering the national economy, providing for citizen welfare, and benefiting all sectors of industry in general and ICT in particular. The ecosystem of efficiently utilizing ICT in achieving real government transformation includes changing the way governments function and work, developing the ICT skills of general citizens and government employees, and encouraging businesses to use ICT.

The results of this research will be useful to people living in Bahrain and to businesses, government authorities, policymakers, and researchers. The findings are consistent with the socio-economic benefits outlined above and should be taken into account by policymakers and government strategists. Governments should include transformation initiatives in their vision statements, and their work plans should show how e-government can facilitate these initiatives. In small developing countries like Bahrain, the Council of Ministers or its equivalent should supervise and implement such initiatives while setting clear targets and performance measures to ensure successful transformation. Such measures would result in direct and indirect socio-economic benefits, including transparent and accountable government, a stronger relationship between citizens and government, and efficient and effective utilization of the country's financial and human resources.

\subsection{Limitations and future research}

The cultural and social impacts of government transformation and citizen trust are broad subjects that call for separate studies and are therefore not included in this research. Both factors may play significant roles in this context, and future research in this area, combined with the factors identified in this research, may add significant value to the current literature 
(Bannister \& Connolly, 2011; Bertot, Jaeger, \& Grimes, 2010; Dalton, 2005; Van de Walle \& Bouckaert, 2003). Since this research covers technology, future studies may investigate other factors that have evolved and arisen, such as governmental and political perspectives.

It should be noted that this research adopts a citizen-centric perspective for all constructs and hypotheses proposed. As such, the findings are based only on data collected from citizens residing in Bahrain, a developing country. Similar studies could be conducted in other GCC countries collectively for comparative purposes.

\section{Contribution}

E-government has been proposed as a means of transforming government, improving performance, reducing costs and reversing the decline in citizen trust and confidence in government. However, many e-government initiatives have failed to achieve the expected results. The continued decline in citizen trust suggests that e-government alone is insufficient for real government transformation. The failure of e-government initiatives may be attributable in part to a focus on technical aspects rather the core functions of government and the lack of agreement on a common set of factors contributing to the decline in citizen trust and confidence in government. By exploring the relationship between transformation of government and citizen trust from the citizen perspective, this study makes three important contributions.

First, this study contributes to the body of knowledge in this field as the first to investigate the relationship between transformation and citizen trust and confidence in government from the perspective of citizens. The results advance the understanding of how a shift in focus of transformation of government beyond simple digitization and web-enabling of processes to fundamental changes to the core functions and processes of government can influence citizens' perception of and engagement with government. 
Second, by deviating from standard techno- or user-centric theories, this study provides a novel conceptual model based on the core concepts of e-government: transformation of government and improved performance, transparency and accountability. This represents a significant divergence from the decades-old techno-centric view of egovernment based on theories and models derived from private-sector contexts, which has had limited practical effectiveness. This new focus on the core concepts of e-government and their interrelationships with fundamental changes in the structure and function of government (through digital-enabled transformation of government) represents a fresh new approach.

Third, testing of the conceptual model in the context of the Kingdom of Bahrain demonstrated that digital-enabled transformation of government initiatives are working well in this country. The success of digital-enabled transformation of government in Bahrain is attributable to its small size and relatively homogeneous demographic composition, the relative maturity of its digital government initiatives, and the complete commitment of the government to these initiatives.

This research ultimately finds that real transformation of government is an important element of the socio-economic development of any country.

\section{Conclusions}

This study confirms that, in Bahrain, citizen trust and confidence in government is influenced by government transformation. Key factors affecting this transformation include the implementation of e-government and other innovative technologies in government departments; management of citizen expectations; and improved accountability and transparency in all functions of government. This transformation may result in improved government performance and an increase in the number of satisfied citizens, thereby ultimately restoring citizen trust in government. 
This research synthesized the literature on information systems in general and digitalenabled transformation of government in particular. The resultant conceptual model and hypotheses were verified in the context of Bahrain. Additionally, several suggestions were provided for policymakers to consider. In developing countries, all related factors should be considered and linked when seeking real digital-enabled transformation of government. The focus of utilizing ICT should be the issuance of policies, which is the core function of governments, and the ultimate goal should be enhancing citizen trust in government.

\section{References}

Abhichandani, T., Horan, T. A., \& Rayalu, R. (2005, October). EGOVSAT: Toward a robust measure of e-government service satisfaction in transportation. In D. Remenyi (Ed.), ICEG 2005. Proceedings of the international conference on e-government (pp. 1-12). Red Hook, NY: Curran Associates, Inc.

Abu-Shanab, E., \& Al-Azzam, A. (2012). Trust dimensions and the adoption of egovernment in Jordan. International Journal of Information Communication Technologies and Human Development, 4(1), 39-51. 
Alderete, M. V. (2017). Examining the ICT access effect on socioeconomic development: the moderating role of ICT use and skills. Information Technology for Development, 23(1), $42-58$.

Al-Khouri, A. M. (2012). eGovernment strategies the case of the United Arab Emirates (UAE). European Journal of ePractice, 17, 126-150.

Al Rub, S. (2006). The impact of information technology on business performance management (The study of the Affairs Agency of Sudanese Working Abroad for the period 2000-2005) (Unpublished master's thesis). University of Science and Technology, Omdurman, Sudan.

Al-Sobhi, F., Weerakkody, V., \& Kamal, M. M. (2010). An exploratory study on the role of intermediaries in delivering public services in Madinah City: Case of Saudi Arabia. Transforming Government: People, Process and Policy, 4(1), 14-36.

Andersen, K. V., \& Henriksen, H. Z. (2006). E-Government maturity models: Extension of the Layne and Lee model. Government Information Quarterly, 23(2), 236-248.

Ashaye, O. R., \& Irani, Z. (2014). E-government implementation benefits, risks, and barriers in developing countries: Evidence from Nigeria. US-China Education Review, 4(1), 1325.

Bannister, F., \& Connolly, R. (2011). Trust and transformational government: A proposed framework for research. Government Information Quarterly, 28(2), 137-147.

Barnes, C., \& Gill, D. (2000). Declining government performance? Why citizens don't trust government (Working paper No. 9). Retrieved from New Zealand State Services Commission website: http://www.ssc.govt.nz/wp9

Baum, C., \& Di Maio, A. (2000). Gartner's four phases of e-Government model. New York, NY: Gartner Group. 
Bearden, W. O., \& Teel, J. E. (1983). Selected determinants of consumer satisfaction and complaint reports. Journal of Marketing Research, 20(1), 21-28.

Bélanger, F., \& Carter, L. (2008). Trust and risk in e-government adoption. The Journal of Strategic Information Systems, 17(2), 165-176.

Bellamy, C., \& Taylor, J. (1998). Governing in the information age. Berkshire, UK: Open University Press.

Bertot, J. C., Jaeger, P. T., \& Grimes, J. M. (2010). Using ICTs to create a culture of transparency: E-government and social media as openness and anti-corruption tools for societies. Government Information Quarterly, 27(3), 264-271.

Bhuasiri, W., Zo, H., Lee, H., \& Ciganek, A. P. (2016). User acceptance of e-government services: Examining an e-tax filing and payment system in Thailand. Information Technology for Development, 22(4), 672-695.

Bouckaert, G., Van de Walle, S., \& Kampen, J. K. (2005). Potential for comparative public opinion research in public administration. International Review of Administrative Sciences, 71(2), 229-240.

Brown, D. (1999). Information systems for improved performance management: Development approaches in US public agencies. In R. Heeks (Ed.), Reinventing government in the information age (pp. 321-330). New York, NY: Routledge.

Cadotte, E. R., Woodruff, R. B., \& Jenkins, R. L. (1987). Expectations and norms in models of consumer satisfaction. Journal of Marketing Research, 24(3), 305-314.

Carter, L., \& Bélanger, F. (2005). The utilization of egovernment services: Citizen trust, innovation and acceptance factors. Information Systems Journal, 15(1), 5-25.

Carter, L., \& Weerakkody, V. (2008). E-government adoption: A cultural comparison. Information Systems Frontiers, 10(4), 473-482. 
Chatfield, A. T. (2009). Public service reform through e-government: A case study of 'e-Tax' in Japan. Electronic Journal of e-Government, 7(2), 135-146.

Chen, K. C., Wei, K. C., \& Chen, Z. (2003). Disclosure, corporate governance, and the cost of equity capital: Evidence from Asia's emerging markets. Retrieved from $\underline{\text { http://dx.doi.org/10.2139/ssrn.422000 }}$

Churchill, G. A., Jr., \& Surprenant, C. (1982). An investigation into the determinants of customer satisfaction. Journal of Marketing Research, 19(4), 491-504.

Comrey, A., \& Lee, H. (1992). A first course in factor analysis. Hillsdale, NJ: Lawrence Erlbaum Associates.

Coursey, D., \& Norris, D. F. (2008). Models of e-government: Are they correct? An empirical assessment. Public Administration Review, 68(3), 523-536.

Dalton, R. J. (2005). The social transformation of trust in government. International Review of Sociology, 15(1), 133-154.

Demchak, C. C., Friis, C. S., \& La Porte, T. M. (2000). Webbing governance: National differences in constructing the face of public organizations. In G. D. Garson (Ed.), Handbook of public information systems (pp. 179-196). New York, NY: Marcel Dekker.

Donnelly, M., Wisniewski, M., Dalrymple, J., \& Curry, A. (1995). Measuring service quality in local government: The SERVQUAL approach. International Journal of Public Sector Management, 8(7), 15-20.

Estevez, E., \& Janowski, T. (2013). Electronic governance for sustainable development: Conceptual framework and state of research. Government Information Quarterly, 30(Suppl.1), S94-S109.

Fang, Z. (2002). E-government in the digital era: Concept, practice, and development. International Journal of the Computer, the Internet and Management, 10(2), 1-22. 
Florini, A. (2000, April). Does the invisible hand need a transparent glove? The politics of transparency. Paper presented at the World Bank Annual Conference on Development Economics, Washington, D.C.

Fornell, C., \& Larcker, D. F. (1981). Evaluating structural equation models with unobservable variables and measurement error. Journal of Marketing Research, 18(1), $39-50$.

Fornell, C., Johnson, M. D., Anderson, E. W., Cha, J., \& Bryant, B. E. (1996). The American customer satisfaction index: Nature, purpose and findings. Journal of Marketing, 60(4), $7-18$.

Fornell, C., Mithas, S., \& Morgeson, F. V., III (2009a). Commentary: The economic and statistical significance of stock returns on customer satisfaction. Marketing Science, $28(5), 820-825$.

Fornell, C., Mithas, S., \& Morgeson, F. V., III (2009b). The statistical significance of portfolio returns. International Journal of Research in Marketing, 26(2), 162-163.

Fountain, J. (2001). Building the virtual state: Information technology and institutional change. Washington, D.C.: Brookings Institution Press.

Fowler, F. J., Jr. (2002). Survey research methods. London, UK: Sage Publications Inc.

Freeman, R. E. (2010). Strategic management: A stakeholder approach. Cambridge, UK: Cambridge University Press.

Garcia-Murillo, M. (2013). Does a government web presence reduce perceptions of corruption? Information Technology for Development, 19(2), 151-175.

Gilbert, D., \& Balestrini, P. (2004). Barriers and benefits in the adoption of e-government. The International Journal of Public Sector Management, 17(4), 286-301. 
Graham, M., \& Avery, E. J. (2013). Government public relations and social media: An analysis of the perceptions and trends of social media use at the local government level. Public Relations Journal, 7(4), 1-21.

Grimmelikhuijsen, S. (2009). Do transparent government agencies strengthen trust? Information Polity, 14(3), 173-186

Gunawong, P., \& Gao, P. (2017). Understanding e-government failure in the developing country context: A process-oriented study. Information Technology for Development, 23(1), 153-178.

Hameed, S., \& Al-Shawabkah, A. (2013). Role of e-government in improving organizational performance in the civil status and passport department of Jordan. Developing Country Studies, 3(5), 50-64.

Hanna, N. (2009). e-Transformation: Enabling new development strategies. New York, NY: Springer.

Heintzman, R., \& Marson, B. (2005). People, service and trust: Is there a public sector service value chain? International Review of Administrative Sciences, 71(4), 549-575.

Hiller, J. S., \& Bélanger, F. (2001). Privacy strategies for electronic government. Egovernment series. Retrieved from the website of IBM Center for The Business of Government: http://www.businessofgovernment.org/pdfs/HillerReport.pdf

Hong, H. (2013). Government websites and social media's influence on government-public relationships. Public Relations Review, 39(4), 346-356.

Huse, M. (2005). Accountability and creating accountability: A framework for exploring behavioural perspectives of corporate governance. British Journal of Management, 16(s1), S65-S79. 
International Labour Organization. (2015). World employment and social outlook: Trends 2015. Retrieved from http://www.ilo.org/global/research/global-reports/weso/2015/lang-en/index.htm

International Labour Organization. (2016). World employment and social outlook: Trends 2016. Retrieved from http://www.ilo.org/global/research/globalreports/weso/2016/WCMS_443480/lang--en/index.htm

International Labour Organization. (2017). World employment and social outlook: Trends 2017. Retrieved from http://www.ilo.org/global/research/global-reports/weso/2017/lang-en/index.htm

Institute of Social and Ethical Accountability. (1999). Accountability 1000. London, UK: Author.

James, O. (2009). Evaluating the expectations disconfirmation and expectations anchoring approaches to citizen satisfaction with local public services. Journal of Public Administration Research and Theory, 19(1), 107-123.

Kampen, J. K., Maddens B., Vermunt, J. K., \& Salminen, A. (2003). Trust and satisfaction: A case study of micro-performance. In A. Salminen (Ed.), Governing networks: EGPA yearbook (pp. 319-326). Amsterdam: IOS Press.

Kampen, J. K., Van De Walle, S. V., \& Bouckaert, G. (2006). Assessing the relation between satisfaction with public service delivery and trust in government: The impact of the predisposition of citizens toward government on evaluations of its performance. Public Performance \& Management Review, 29(4), 387-404.

Khalil, O. E. (2011). e-Government readiness: Does national culture matter? Government Information Quarterly, 28(3), 388-399.

Kim, S., Kim, H. J., \& Lee, H. (2009). An institutional analysis of an e-government system for anti-corruption: The case of OPEN. Government Information Quarterly, 26(1), 42-50. 
Layne, K., \& Lee, J. (2001). Developing fully functional e-government. Government Information Quarterly, 18(2), 122-136.

Luna-Reyes, L. F., \& Gil-García, J. R. (2011). Using institutional theory and dynamic simulation to understand complex e-government phenomena. Government Information Quarterly, 28(3), 329-345.

McKnight, D. H., Choudhury, V., \& Kacmar, C. (2002). Developing and validating trust measures for e-commerce: An integrative typology. Information Systems Research, 13(3), $334-359$.

McNeal, R., Hale, K., \& Dotterweich, L. (2008). Citizen-government interaction and the internet: Expectations and accomplishments in contact, quality, and trust. Journal of Information Technology \& Politics, 5(2), 213-229.

Meijer, A. J., Koops, B. J., Pieterson, W., Overman, S., \& Tije, S. (2012). Government 2.0: Key challenges to its realization. Electronic Journal of e-Government, 10(1), 59-69

Meso, P., Musa, P., Straub, D., \& Mbarika, V. (2009). Information infrastructure, governance, and socio-economic development in developing countries. European Journal of Information Systems, 18(1), 52-65.

Miyata, M. (2011). Measuring impacts of e-government support in least developed countries: A case study of the vehicle registration service in Bhutan. Information Technology for Development, 17(2), 133-152.

Morgeson, F. V. (2013). Expectations, disconfirmation, and citizen satisfaction with the US federal government: Testing and expanding the model. Journal of Public Administration Research and Theory, 23(2), 289-305.

Morgeson, F. V., \& Petrescu, C. (2011). Do they all perform alike? An examination of perceived performance, citizen satisfaction and trust with US federal agencies. International Review of Administrative Sciences, 77(3), 451-479. 
Morgeson, F. V., VanAmburg, D., \& Mithas, S. (2011). Misplaced trust? Exploring the structure of the e-government-citizen trust relationship. Journal of Public Administration Research and Theory, 21(2), 257-283.

Nam, T. (2012). Citizens' attitudes toward open government and government 2.0. International Review of Administrative Sciences, 78(2), 346-368.

Nunnally, J. C., \& Bernstein, I. H. (1994). Psychometric theory (3rd ed.). New York, NY: McGraw-Hill.

O'Donnell, M., \& Turner, M. (2013). Leading the world: Public sector reform and egovernment in Korea. The Economic and Labour Relations Review, 24(4), 533-548.

Omar, A., Weerakkody, V., \& Sivarajah, U. (2017). Digitally enabled service transformation in UK public sector: A case analysis of universal credit. International Journal of Information Management, 37(4), 350-356.

Orlikowski, W. J. (1992). The duality of technology: Rethinking the concept of technology in organizations, Organization Science, 3(3), 398-427.

Orlikowski, W. J. (2000). Using technology and constituting structures: A practice lens for studying technology in organizations, Organization Science, 11(4), 404-428.

Orlikowski, W. J., Yates, J., Okamura, K., \& Fujimoto, M. (1995). Shaping electronic communication: The meta-structuring of technology in the context of use. Organization Science, 6(4), 423-444.

Palvia, P., Baqir, N., \& Nemati, H. (2017). ICT for socio-economic development: A citizens' perspective. Information \& Management. Advance online publication. https://doi.org/10.1016/j.im.2017.05.003

Parasuraman, A., Berry, L. L., \& Zeithaml, V. A. (1991). Refinement and reassessment of the SERVQUAL scale. Journal of Retailing, 67(4), 420-450. 
Parasuraman, A., Zeithaml, V. A., \& Berry, L. L. (1988). SERVQUAL: A multiple-item scale for measuring consumer perceptions of service quality. Journal of Retailing, 64(1), $12-40$.

Park, H., \& Blenkinsopp, J. (2011). The roles of transparency and trust in the relationship between corruption and citizen satisfaction. International Review of Administrative Sciences, 77(2), 254-274.

Paroški, M., Konjović, Z., Surla, D., \& Popović, V. (2015). Development of e-government services in the autonomous province of Vojvodina. Information Technology for Development, 21(3), 492-510.

Patterson, M. G., West, M. A., Shackleton, V. J., Dawson, J. F., Lawthom, R., Maitlis, S., \& Wallace, A. M. (2005). Validating the organizational climate measure: Links to managerial practices productivity and innovation. Journal of Organizational Behavior, 26(4), 379-408.

Pina, V., Torres, L., \& Royo, S. (2009). E-government evolution in EU local governments: A comparative perspective. Online Information Review, 33(6), 1137-1168.

Roberts, J., \& Scapens, R. (1985). Accounting systems and systems of accountability: Understanding accounting practices in their organisational contexts. Accounting, Organizations and Society, 10(4), 443-456.

Rodrigues, G., Sarabdeen, J., \& Balasubramanian, S. (2016). Factors that influence consumer adoption of e-government services in the UAE: A UTAUT model perspective. Journal of Internet Commerce, 15(1), 18-39.

Rodríguez Bolívar, M. P., Alcaide Muñoz, L., \& López Hernández, A. M. (2016). Scientometric study of the progress and development of e-government research during the period 2000-2012. Information Technology for Development, 22(1), 36-74. 
Roztocki, N., \& Weistroffer, H. R. (2016). Conceptualizing and researching the adoption of ICT and the impact on socioeconomic development. Information Technology for Development, 22(4), 541-549

Said, J., Iaafar, N. H., \& Atan, R. (2015). Assessing accountability in government linked companies: An empirical evidence. International Business Management, 9(4), 460-469.

Salmi, M., \& Hasnan, N. (2016). E-government technology acceptance analysis of citizens: Sultanate of Oman case. International Journal of Social Relevance \& Concern, 4(1), 1326.

Samoilenko, S., \& Osei-Bryson, K. M. (2017). An analytical framework for exploring context-specific micro-economic impacts of ICT capabilities. Information Technology for Development. Advance online publication. doi:10.1080/02681102.2017.1336072

Scholl, H. J. (2001). Applying stakeholder theory to e-government. In B. Schmidt, K. Stanoevska-Slabeva, \& V. Tschammer (Eds.), Towards the e-society: e-commerce, $e$ business and e-government (pp. 735-748). Norwell, MA: Kluwer Academic Publishers.

Scott, M., Golden, W., \& Hughes, M. (2004). The implementation of citizen-centred egovernment: A stakeholder viewpoint. Retrieved from http://hdl.handle.net/10379/32

Seifert, J. W., \& Petersen, R. E. (2002). The promise of all things E? Expectations and challenges of emergent electronic government. Perspectives on Global Development and Technology, 1(2), 193-212.

Sharma, S. K., Govindaluri, S. M., \& Gattoufi, S. (2015). Understanding and predicting the quality determinants of e-government services: A two-staged regression-neural network model. Journal of Modelling in Management, 10(3), 325-340.

Song, C., \& Lee, J. (2013, June). Can social media restore citizen trust in government? Paper presented at the Public Management Research Conference, Madison, WI. 
Swift, T. (2001). Trust, reputation and corporate accountability to stakeholders. Business Ethics: A European Review, 10(1), 16-26.

Tabachnick, B. G., Fidell, L. S., \& Osterlind, S. J. (2001). Using multivariate statistics. New York, NY: Pearson.

Tennert, J. R., \& Schroeder, A. D. (1999, April). Stakeholder analysis. Paper presented at the $60^{\text {th }}$ Annual Meeting of the American Society for Public Administration, Orlando, FL.

Teo, T. S., Srivastava, S. C., \& Jiang, L. (2008). Trust and electronic government success: An empirical study. Journal of Management Information Systems, 25(3), 99-132.

Tolbert, C. J., \& Mossberger, K. (2006). The effects of egovernment on trust and confidence in government. Public Administration Review, 66(3), 354-369.

United Nations. (2012). E-Government survey 2012: e-Government for the people. Retrieved from the website of the Division for Public Administration and Development Management, Department of Economic and Social Affairs, United Nations: https://publicadministration.un.org/egovkb/en-us/Reports/UN-E-Government-Survey2012

United Nations. (2014). E-Government survey 2014: e-Government for the future we want. Retrieved from the website of the Division for Public Administration and Development Management, Department of Economic and Social Affairs, United Nations: https://publicadministration.un.org/egovkb/en-us/Reports/UN-E-Government-Survey2014

United Nations. (2016). E-Government survey 2016: e-Government in support of sustainable development. Retrieved from the website of the Division for Public Administration and Development Management, Department of Economic and Social Affairs, United Nations: https://publicadministration.un.org/egovkb/en-us/Reports/UN-E-Government-Survey2016 
Van de Walle, S., \& Bouckaert, G. (2003). Public service performance and trust in government: The problem of causality. International Journal of Public Administration, 26(8-9), 891-913.

Van de Walle, S., Van Roosbroek, S., \& Bouckaert, G. (2008). Trust in the public sector: Is there any evidence for a long-term decline? International Review of Administrative Sciences, 74(1), 47-64.

Van Ryzin, G. G., Muzzio, D., Immerwahr, S., Gulick, L., \& Martinez, E. (2004). Drivers and consequences of citizen satisfaction: an application of the American customer satisfaction index model to New York City. Public Administration Review, 64(3), 331341.

Waller, P., \& Weerakkody, V. (2016). Digital government: Overcoming the systemic failure of transformation (Working Paper 2). London, UK: Brunel University

Weerakkody, V., El-Haddadeh, R., Al-Sobhi, F., Shareef, M. A., \& Dwivedi, Y. K. (2013). Examining the influence of intermediaries in facilitating e-government adoption: An empirical investigation. International Journal of Information Management, 33(5), 716725.

Weerakkody, V., Janssen, M., \& Dwivedi, Y. (Eds.). (2009). Handbook of research on ICT enabled transformational government: A global perspective. Hershey, PA: Information Science Reference.

Welch, E. W., Hinnant, C. C., \& Moon, M. J. (2005). Linking citizen satisfaction with egovernment and trust in government. Journal of Public Administration Research and Theory, 15(3), 371-391.

West, D. M. (2004). E-government and the transformation of service delivery and citizen attitudes. Public Administration Review, 64(1), 15-27. 
Williams, P. F. (1987). The legitimate concern with fairness. Accounting, Organizations and Society, 12(2), 169-189.

Wood, M., \& Welch, C. (2010). Are 'qualitative' and 'quantitative' useful terms for describing research? Methodological Innovations Online, 5(1), 56-71.

Yamin, M., \& Mattar, R. (2016). e-Government in Saudi Arabia: An empirical study. BVICAM's International Journal of Information Technology, 8(1), 944-949.

Zhang, J. (2013). Towards a citizen-centered e-government: Exploring citizens' satisfaction with e-government in China (Doctoral dissertation). Retrieved from ProQuest Dissertations and Theses. (Publication No. 3596682). Retrieved from https://search.proquest.com/openview/779b13a52e70b97e56b8e9f3c7f4419c/1.pdf?pqorigsite $=$ gscholar $\& \mathrm{cbl}=18750 \&$ diss $=\mathrm{y}$

Zhao, F., Wallis, J., \& Singh, M. (2015). E-government development and the digital economy: A reciprocal relationship. Internet Research, 25(5), 734-766.

Zouridis, S., \& Thaens, M. (2003). E-government: Towards a public administration approach. Asian Journal of Public Administration, 25(2), 159-183. 
Table 1. Research Instruments and Evidence from the Literature

\begin{tabular}{|c|c|c|c|}
\hline Construct & $\begin{array}{l}\text { Relationship } \\
\text { Affected }\end{array}$ & $\begin{array}{l}\text { Supporting Literature for } \\
\text { the Relationship }\end{array}$ & Supporting Theories \\
\hline EGOV & $\begin{array}{l}\text { EGOV } \rightarrow \\
\text { TRANSF }\end{array}$ & $\begin{array}{l}\text { Andersen and Henriksen } \\
(2006) ; \quad \text { Bannister and } \\
\text { Connolly (2011); Bellamy } \\
\text { and Taylor (1998); Baum and } \\
\text { Di Maio (2000); Coursey and } \\
\text { Norris (2008); Layne and Lee } \\
\text { (2001) }\end{array}$ & 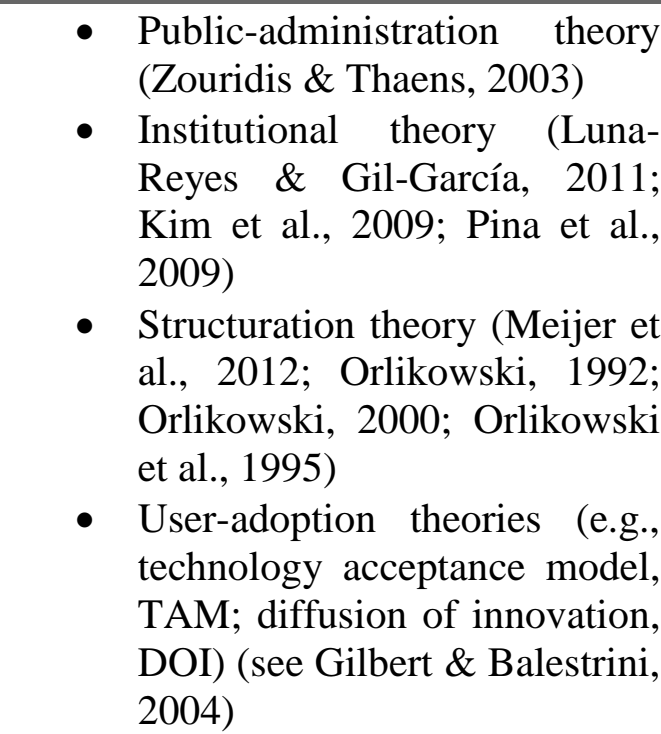 \\
\hline TECH & $\begin{array}{l}\text { TECH } \rightarrow \\
\text { TRANSF }\end{array}$ & $\begin{array}{l}\text { Bannister and Connolly } \\
\text { (2011); Kim et al. (2009); } \\
\text { Weerakkody, Janssen, \& } \\
\text { Dwivedi (2009) }\end{array}$ & 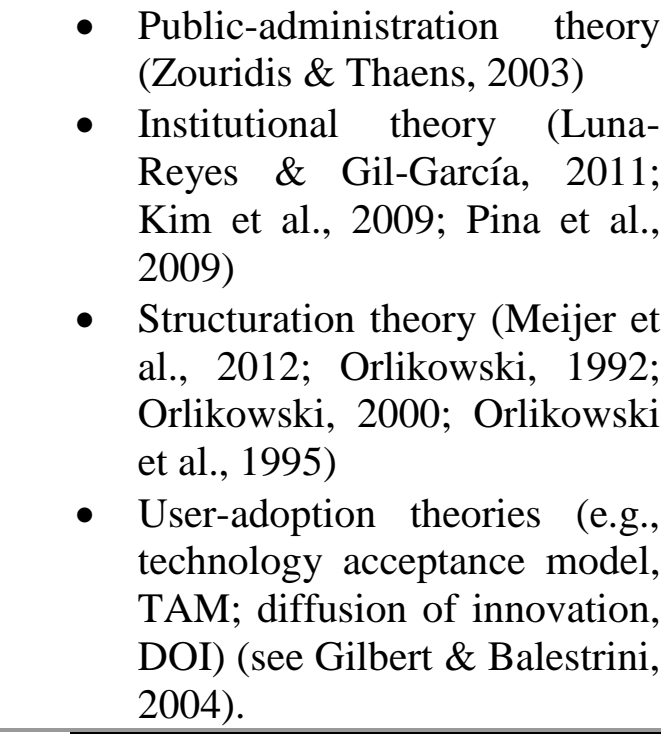 \\
\hline $\begin{array}{l}\text { TRANSP } \\
\text { Y }\end{array}$ & $\begin{array}{l}\text { TRANSPY } \\
\rightarrow \text { TRANSF }\end{array}$ & $\begin{array}{l}\text { Brown } \quad(1999) ; \quad \text { Fountain } \\
(2001)\end{array}$ & $\begin{array}{l}\text { - Public-administration theory } \\
\text { (Zouridis \& Thaens, 2003) } \\
\text { - Agent-principal theory (Kim et } \\
\text { al., 2009) } \\
\text { - Institutional theory (Kim et al., } \\
\text { 2009) }\end{array}$ \\
\hline $\begin{array}{l}\text { ACCOUN } \\
\text { T }\end{array}$ & $\begin{array}{l}\text { ACCOUNT } \\
\rightarrow \text { TRANSF }\end{array}$ & $\begin{array}{l}\text { Bannister and Connolly } \\
\text { (2011); Demchak, Friis, and } \\
\text { La Porte (2000); Kim et al. } \\
\text { (2009 }\end{array}$ & 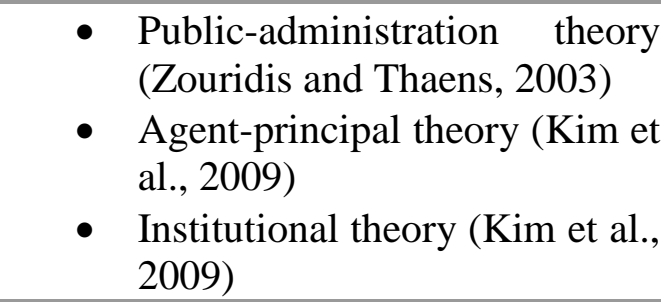 \\
\hline EXPEC & $\mathrm{EXPEC} \rightarrow$ & $\begin{array}{l}\text { Dalton (2005); Graham and } \\
\text { Avery (2013); Seifert and }\end{array}$ & $\begin{array}{l}\text { Stakeholder theory (Scholl, 2001; } \\
\text { Tennert \& Schroeder, 1999) }\end{array}$ \\
\hline
\end{tabular}




\begin{tabular}{|c|c|c|c|}
\hline & TRANSF & $\begin{array}{l}\text { Petersen, (2002); Welch et al. } \\
\text { (2005) }\end{array}$ & \\
\hline TRANSF & $\begin{array}{l}\text { TRANSF } \rightarrow \\
\text { PERFO }\end{array}$ & $\begin{array}{l}\text { Chatfield (2009); Fang } \\
\text { (2002); Florini (2000); Kim } \\
\text { et al. (2009) }\end{array}$ & $\begin{array}{l}\text { Public-administration theory (Zouridis } \\
\& \text { Thaens, 2003) }\end{array}$ \\
\hline PERFO & $\begin{array}{l}\text { PERFO } \rightarrow \\
\text { SATISF }\end{array}$ & $\begin{array}{l}\text { Bouckaert et al. (2005); } \\
\text { Heintzman and Marson } \\
\text { (2005); Kampen et al. (2006); } \\
\text { Tolbert and Mossberger } \\
\text { (2006); Van de Walle and } \\
\text { Bouckaert (2003); Van de } \\
\text { Walle, Van Roosbroek, and } \\
\text { Bouckaert (2008) }\end{array}$ & $\begin{array}{l}\text { Micro-performance theory (Kampen } \\
\text { et al., 2006; Kampen, et al., 2003; Van } \\
\text { de Walle \& Bouckaert, 2003) }\end{array}$ \\
\hline SATISF & $\begin{array}{l}\text { SATISF } \rightarrow \\
\text { TRUST \& } \\
\text { CONFIDEN } \\
\text { CE }\end{array}$ & $\begin{array}{l}\text { Bannister and Connolly } \\
\text { (2011); Bouckaert, Van de } \\
\text { Walle and Kampen, (2005); } \\
\text { Heintzman and Marson } \\
\text { (2005); Tolbert and } \\
\text { Mossberger (2006); Van de } \\
\text { Walle and Bouckaert (2003); } \\
\text { Van de Walle et al. (2008); } \\
\text { Welch et al. (2005) }\end{array}$ & $\begin{array}{l}\text { Micro-performance theory (Kampen } \\
\text { et al., 2006; Kampen et al., 2003; Van } \\
\text { de Walle \& Bouckaert, 2003) }\end{array}$ \\
\hline $\begin{array}{l}\text { TRUST \& } \\
\text { CONFIDE } \\
\text { NCE }\end{array}$ & --- & --- & $\begin{array}{l}\text { - Micro-performance theory } \\
\text { (Van de Walle \& Bouckaert, } \\
\text { 2003) } \\
\text { - Exit-voice theory (Fornell et } \\
\text { al., 1996; Morgeson et al., } \\
\text { 2011) }\end{array}$ \\
\hline
\end{tabular}


Table 2. GCC global ranking - UN EGDI.

\begin{tabular}{|c|c|c|c|c|}
\hline \multirow{2}{*}{} & \multicolumn{4}{|c|}{$\begin{array}{c}\text { e-Government Development Index (EGDI) } \\
\text { Ranking }\end{array}$} \\
\cline { 2 - 5 } & 2005 & 2012 & 2014 & 2016 \\
\hline Bahrain & 53 & 36 & 18 & 24 \\
\hline KSA & 80 & 41 & 36 & 44 \\
\hline Qatar & 62 & 48 & 44 & 48 \\
\hline UAE & 42 & 28 & 32 & 29 \\
\hline Oman & 112 & 64 & 48 & 66 \\
\hline Kuwait & 75 & 63 & 49 & 40 \\
& & & & \\
\hline
\end{tabular}

Source: United Nations (2016) 
Table 3. Research constructs and measuring items.

\begin{tabular}{|c|c|c|}
\hline Construct & $\begin{array}{c}\text { Measuring } \\
\text { Items }\end{array}$ & Adopted from \\
\hline E-Government (EGOV) & Q1-Q10 & $\begin{array}{c}\text { Abhichandani, Horan, and Rayalu } \\
\text { (2005) }\end{array}$ \\
\hline Transparency (TRANSPY) & Q11-Q15 & Park and Blenkinsopp (2011) \\
\hline Accountability (ACCOUNT) & Q16-Q20 & Said, Iaafar, and Atan (2015) \\
\hline Technology (TECH) & Q21-Q23 & Hameed and Al-Shawabkah (2013) \\
\hline Expectations (EXPEC) & Q24-Q36 & Parasuraman et al. (1988) \\
\hline Transformation (TRANSF) & Q37-Q41 & Patterson et al. (2005) \\
\hline Performance (PERFO) & Q42-Q45 & Zhang (2013) \\
\hline Satisfaction (SATISF) & Q46-Q50 & Zhang (2013) \\
\hline Trust \& Confidence (TRU_COF) & Q51-Q55 & $\begin{array}{c}\text { McKnight, Choudhury, and Kacmar } \\
\text { (2002); Morgeson et al. (2011) }\end{array}$ \\
\hline
\end{tabular}


Table 4. Profile of the respondents.

\begin{tabular}{|c|c|c|c|c|c|c|c|}
\hline Gender & Freq $(\%)$ & Age & Freq $(\%)$ & Education & Freq $(\%)$ & Income & Freq (\%) \\
\hline Male & $195(62.3)$ & $<18$ & $3(1.0)$ & $\begin{array}{l}\text { Less than } \\
\text { secondary } \\
\text { school }\end{array}$ & $0(0)$ & $\begin{array}{c}\text { Under US\$5 } \\
00\end{array}$ & 78 (24.9) \\
\hline \multirow[t]{4}{*}{ Female } & \multirow[t]{4}{*}{$118(37.7)$} & $18-30$ & $142(45.4)$ & $\begin{array}{c}\text { Secondary } \\
\text { school }\end{array}$ & $11(3.5)$ & $\begin{array}{l}\text { US } \$ 500 /- \text { to } \\
\text { US } \$ 1,000 /- \\
\text { US } \$ 1,000 /-\end{array}$ & $22(7)$ \\
\hline & & $31-40$ & $90(28.8)$ & \multirow{3}{*}{$\begin{array}{c}\text { Diploma } \\
\text { Bachelor's } \\
\text { degree } \\
\text { Master's } \\
\text { degree }\end{array}$} & $22(7.0)$ & $\begin{array}{c}\text { to } \\
\text { US\$1,500/- } \\
\text { US\$1,500/- }\end{array}$ & $21(6.7)$ \\
\hline & & $41-50$ & $45(14.4)$ & & $184(58.8)$ & $\begin{array}{c}\text { to } \\
\text { US\$2,000/- } \\
\text { More than }\end{array}$ & $22(7)$ \\
\hline & & $>50$ & $33(10.5)$ & & $96(30.7)$ & US\$2,000/- & $170(54.4)$ \\
\hline Total & & & & 313 & & & \\
\hline
\end{tabular}


Table 5. Results of confirmatory factor analysis

\begin{tabular}{|c|c|c|c|c|c|c|c|c|c|c|c|}
\hline & CR & AVE & SATISF & EGOV & TRANSPY & ACCOUNT & TECH & EXPEC & TRANSF & PERFO & TRU_COF \\
\hline SATISF & 0.932 & 0.733 & 0.856 & & & & & & & & \\
\hline EGOV & 0.897 & 0.594 & 0.756 & 0.771 & & & & & & & \\
\hline TRANSPY & 0.844 & 0.576 & 0.754 & 0.83 & 0.759 & & & & & & \\
\hline ACCOUNT & 0.862 & 0.61 & 0.738 & 0.796 & 0.899 & 0.781 & & & & & \\
\hline TECH & 0.771 & 0.53 & 0.782 & 0.769 & 0.887 & 0.966 & 0.728 & & & & \\
\hline EXPEC & 0.946 & 0.614 & 0.81 & 0.731 & 0.846 & 0.882 & 0.896 & 0.783 & & & \\
\hline TRANSF & 0.925 & 0.711 & 0.608 & 0.569 & 0.773 & 0.791 & 0.74 & 0.855 & 0.843 & & \\
\hline PERFO & 0.899 & 0.691 & 0.948 & 0.783 & 0.791 & 0.775 & 0.796 & 0.821 & 0.656 & 0.831 & \\
\hline TRU_COF & 0.936 & 0.745 & 0.791 & 0.674 & 0.75 & 0.785 & 0.771 & 0.85 & 0.785 & 0.774 & 0.863 \\
\hline
\end{tabular}


Table 6. Mean, std. deviation and correlation.

\begin{tabular}{|c|c|c|c|c|c|c|c|c|c|}
\hline & Mean & Std. Deviation & EGOV & TRANSPY & ACCOUNT & ТЕCH & EXPEC & TRANSF & PERFO \\
\hline EGOV & 37.0224 & 10.66008 & & & & & & & \\
\hline TRANSPY & 15.2115 & 4.9846 & $.786^{* *}$ & & & & & & \\
\hline ACCOUNT & 15.609 & 5.07264 & $.744 * *$ & $.761 * *$ & & & & & \\
\hline TECH & 12.8494 & 3.95403 & $.707 * *$ & $.698 * *$ & $.758 * *$ & & & & \\
\hline EXPEC & 42.8109 & 13.61511 & $.731 * *$ & $.748 * *$ & $.794 * *$ & $.748 * *$ & & & \\
\hline TRANSF & 17.5641 & 7.02849 & $.566 * *$ & $.678 * *$ & $.691 * *$ & $.587 * *$ & $.787 * *$ & & \\
\hline PERFO & 16.6603 & 5.35652 & $.722 * *$ & $.691 * *$ & $.689 * *$ & $.672 * *$ & $.756 * *$ & $.602 * *$ & \\
\hline SATISF & 21.6667 & 6.7338 & $.709 * *$ & $.670 * *$ & $.662 * *$ & $.667 * *$ & $.759 * *$ & $.553 * *$ & $.860 * *$ \\
\hline
\end{tabular}


Table 7. Path analysis results

\begin{tabular}{|c|c|c|c|}
\hline$\#$ & Path & $\begin{array}{c}\text { Standardized } \\
\text { Coefficient (t) } \mathbf{p}\end{array}$ & Results \\
\hline H1a & EGOV $\rightarrow$ TRANSF & $-0.140(-11.6666667)^{* * *}$ & Supported \\
\hline H1b & TECH $\rightarrow$ TRANSF & $-0.694(-57.8333333)^{* * *}$ & Supported \\
\hline H1c & EXPEC $\rightarrow$ TRANSF & $0.323(26.9166667)^{* * *}$ & Supported \\
\hline H1d & TRANSPY $\rightarrow$ TRANSF & $0.154(12.8333333)^{* * *}$ & Supported \\
\hline H1e & ACCOUNT $\rightarrow$ TRANSF & $0.605(50.4166667)^{* * *}$ & Supported \\
\hline H2 & TRANSF $\rightarrow$ PERFO & $0.957(79.75)^{* * *}$ & Supported \\
\hline H3 & PERFO $\rightarrow$ SATISF & $0.996(19.92)^{* * *}$ & Supported \\
\hline H4 & SATISF $\rightarrow$ TRU_COF & $0.963(74.0769231)^{* * *}$ & Supported \\
\hline
\end{tabular}

Note: $* p<0.05, * * p<0.01, * * * p<0.001$ 


\section{Appendix 1 - Research Instruments - After Data Analysis}

\begin{tabular}{|c|c|c|}
\hline Construct & & Measuring Items \\
\hline \multirow{6}{*}{ EGOV } & Q1 & $\begin{array}{l}\text { People would learn to use the government department's website very } \\
\text { quickly. }\end{array}$ \\
\hline & Q2 & $\begin{array}{l}\text { I found the information on the government department's website very } \\
\text { useful. }\end{array}$ \\
\hline & Q3 & $\begin{array}{l}\text { I found helpful features on the government department's website for } \\
\text { accomplishing my task. }\end{array}$ \\
\hline & Q4 & $\begin{array}{l}\text { Through every step of navigation through the website, I found the } \\
\text { government department's website to consistently provide useful } \\
\text { information. }\end{array}$ \\
\hline & Q5 & $\begin{array}{l}\text { I found that the content in the government department's website was } \\
\text { organized appropriately. }\end{array}$ \\
\hline & Q6 & $\begin{array}{l}\text { I found the design of the government department's website visually } \\
\text { pleasing. }\end{array}$ \\
\hline \multirow{4}{*}{ TRANSPY } & Q7 & $\begin{array}{l}\text { The government department's programs are implemented more } \\
\text { transparently on the website. }\end{array}$ \\
\hline & Q8 & $\begin{array}{l}\text { The government department's decision-making is transparently disclosed } \\
\text { on the website. }\end{array}$ \\
\hline & Q9 & $\begin{array}{l}\text { The citizen can clearly see the progress and situation of decision-making } \\
\text { through the website. }\end{array}$ \\
\hline & Q10 & $\begin{array}{l}\text { The government department's website discloses sufficient and reliable } \\
\text { information on its policies to citizens. }\end{array}$ \\
\hline \multirow{4}{*}{ ACCOUNT } & Q11 & $\begin{array}{l}\text { The government departments recognize their responsibilities toward all } \\
\text { communities. }\end{array}$ \\
\hline & Q12 & The government departments maintain detailed and up-to-date records. \\
\hline & Q13 & $\begin{array}{l}\text { The government departments foster collaboration with other related } \\
\text { agencies. }\end{array}$ \\
\hline & Q14 & $\begin{array}{l}\text { The government departments ensure funds are used properly and in an } \\
\text { authorized manner. }\end{array}$ \\
\hline \multirow{3}{*}{ TECH } & Q15 & $\begin{array}{l}\text { The government departments use computer networks to connect all of } \\
\text { their divisions. }\end{array}$ \\
\hline & Q16 & $\begin{array}{l}\text { The government departments are keen on providing network security in } \\
\text { order to secure information. }\end{array}$ \\
\hline & Q17 & $\begin{array}{l}\text { Data exchange is conducted with great ease among the government } \\
\text { department's divisions through the available means of communication. }\end{array}$ \\
\hline \multirow{8}{*}{ EXPEC } & Q18 & $\begin{array}{l}\text { The government departments show sincere interest in solving citizens' } \\
\text { problems. }\end{array}$ \\
\hline & Q19 & The government departments provide services at the time promised. \\
\hline & Q20 & The government departments maintain error-free records. \\
\hline & Q21 & $\begin{array}{l}\text { The government departments inform citizens when services will be } \\
\text { performed. }\end{array}$ \\
\hline & Q22 & The government departments offer prompt services to citizens. \\
\hline & Q23 & The government departments readily respond to citizens' requests. \\
\hline & Q24 & The government departments are able to instill confidence in citizens. \\
\hline & Q25 & $\begin{array}{l}\text { The government departments ensure that citizens feel safe in their } \\
\text { transactions. }\end{array}$ \\
\hline
\end{tabular}




\begin{tabular}{|c|c|c|}
\hline & Q26 & $\begin{array}{l}\text { The government departments ensure that employees have the knowledge } \\
\text { to answer citizens' questions. }\end{array}$ \\
\hline & Q27 & $\begin{array}{l}\text { The government departments make sure that employees give personal } \\
\text { attention to all. }\end{array}$ \\
\hline & Q28 & $\begin{array}{l}\text { The government departments make sure that employees understand } \\
\text { citizens' needs. }\end{array}$ \\
\hline \multirow{5}{*}{ TRANSF } & Q29 & In government departments, new ideas are readily accepted. \\
\hline & Q30 & $\begin{array}{l}\text { In government departments, management is quick to spot the need to do } \\
\text { things differently. }\end{array}$ \\
\hline & Q31 & $\begin{array}{l}\text { In government departments, responses are quick when changes need to be } \\
\text { made. }\end{array}$ \\
\hline & Q32 & $\begin{array}{l}\text { In government departments, there is flexibility; they can quickly change } \\
\text { procedures to meet new conditions and solve problems as they arise. }\end{array}$ \\
\hline & Q33 & $\begin{array}{l}\text { In government departments, assistance in developing new ideas is readily } \\
\text { available. }\end{array}$ \\
\hline \multirow{4}{*}{ PERFO } & Q34 & $\begin{array}{l}\text { The performance of e-government services related to finding information } \\
\text { is excellent. }\end{array}$ \\
\hline & Q35 & $\begin{array}{l}\text { The performance of e-government services related to completing } \\
\text { transactions is efficient. }\end{array}$ \\
\hline & Q36 & $\begin{array}{l}\text { The performance related to electronic public participation is noticeable } \\
\text { and visible. }\end{array}$ \\
\hline & Q37 & $\begin{array}{l}\text { The overall performance of e-government services is effective and } \\
\text { efficient. }\end{array}$ \\
\hline \multirow{5}{*}{ SATISF } & Q38 & $\begin{array}{l}\text { I was satisfied with my experience when using e-government services } \\
\text { while looking for information I needed. }\end{array}$ \\
\hline & Q39 & $\begin{array}{l}\text { I was satisfied with my experience while completing my e-government } \\
\text { services transactions. }\end{array}$ \\
\hline & Q40 & I was satisfied with the extent of my electronic participation as a citizen. \\
\hline & Q41 & $\begin{array}{l}\text { I was satisfied with the extent of e-government services provided through } \\
\text { multiple channels (e.g. websites; kiosks and mobile phones). }\end{array}$ \\
\hline & Q42 & Overall, I was satisfied with the services provided electronically. \\
\hline \multirow{5}{*}{ TRU_COF } & Q43 & I feel that the government acts in the citizens' best interest. \\
\hline & Q44 & $\begin{array}{l}\text { I feel fine interacting with the government since the government generally } \\
\text { fulfills its duties efficiently. }\end{array}$ \\
\hline & Q45 & I am comfortable relying on the government to meet their obligations. \\
\hline & Q46 & $\begin{array}{l}\text { I always feel confident that I can rely on the government to do their part } \\
\text { when I interact with them. }\end{array}$ \\
\hline & Q47 & $\begin{array}{l}\text { I feel confident that the government department will do a good job } \\
\text { providing the services that I use in the future. }\end{array}$ \\
\hline
\end{tabular}




\section{Appendix 2 - Research Instruments - Before Data Analysis}

\begin{tabular}{|c|c|c|}
\hline Construct & & Measuring Items \\
\hline \multirow{10}{*}{ EGOV } & Q1 & $\begin{array}{l}\text { People would learn to use the government department's website very } \\
\text { quickly. }\end{array}$ \\
\hline & Q2 & $\begin{array}{l}\text { I found information on the government department's website to be very } \\
\text { useful. }\end{array}$ \\
\hline & Q3 & $\begin{array}{l}\text { I found helpful features on the government department's website for } \\
\text { accomplishing my task. }\end{array}$ \\
\hline & Q4 & $\begin{array}{l}\text { Through every step of navigation through the website, I found the } \\
\text { government department's website to consistently provide useful } \\
\text { information. }\end{array}$ \\
\hline & Q5 & $\begin{array}{l}\text { I found that the content in the government department's website was } \\
\text { organized appropriately. }\end{array}$ \\
\hline & Q6 & $\begin{array}{l}\text { I found the design of the government department's website visually } \\
\text { pleasing. }\end{array}$ \\
\hline & Q7 & $\begin{array}{l}\text { I found that various sections within the government department were not } \\
\text { properly linked together. }\end{array}$ \\
\hline & Q8 & I was able to save the transaction details for future reference. \\
\hline & Q9 & $\begin{array}{l}\text { I was able to choose the manner in which I am sent } \\
\text { reminders/notifications about my transaction. }\end{array}$ \\
\hline & Q10 & $\begin{array}{l}\text { I was able to request access to information the way I wanted to (i.e., on } \\
\text { mobile devices or electronic mail) on the days I wanted to. }\end{array}$ \\
\hline \multirow{4}{*}{ TRANSPY } & Q11 & $\begin{array}{l}\text { The government department's programs are implemented more } \\
\text { transparently on the website. }\end{array}$ \\
\hline & Q12 & $\begin{array}{l}\text { The government department's decision-making is transparently disclosed } \\
\text { on the website. }\end{array}$ \\
\hline & Q13 & $\begin{array}{l}\text { The citizen can clearly see the progress and situation of decision-making } \\
\text { through the website. }\end{array}$ \\
\hline & Q14 & $\begin{array}{l}\text { The government department's website discloses sufficient and reliable } \\
\text { information on its policies to citizens. }\end{array}$ \\
\hline \multirow{4}{*}{ ACCOUNT } & Q15 & $\begin{array}{l}\text { The government departments recognize their responsibilities toward all } \\
\text { communities. }\end{array}$ \\
\hline & Q16 & The government departments maintain detailed and up-to-date records. \\
\hline & Q17 & $\begin{array}{l}\text { The government departments foster collaboration with other related } \\
\text { agencies. }\end{array}$ \\
\hline & Q18 & $\begin{array}{l}\text { The government departments ensure funds are used properly and in an } \\
\text { authorized manner. }\end{array}$ \\
\hline \multirow{3}{*}{ TECH } & Q19 & $\begin{array}{l}\text { The government departments use computer networks to connect all of } \\
\text { their divisions. }\end{array}$ \\
\hline & Q20 & $\begin{array}{l}\text { The government departments are keen on providing network security in } \\
\text { order to secure information. }\end{array}$ \\
\hline & Q21 & $\begin{array}{l}\text { Data exchange is conducted with great ease among the government } \\
\text { department's divisions through the available means of communication. }\end{array}$ \\
\hline EXPEC & Q22 & The government departments show sincere interest in solving citizens' \\
\hline
\end{tabular}




\begin{tabular}{|c|c|c|}
\hline & & \\
\hline & Q23 & The government departments provide services at the time promised. \\
\hline & Q24 & The government departments maintain error-free records. \\
\hline & Q25 & $\begin{array}{l}\text { The government departments inform citizens when services will be } \\
\text { performed. }\end{array}$ \\
\hline & Q26 & The government departments offer prompt services to citizens. \\
\hline & Q27 & The government departments readily respond to citizens' requests. \\
\hline & Q28 & The government departments are able to instill confidence in citizens. \\
\hline & Q29 & $\begin{array}{l}\text { The government departments ensure that citizens feel safe in their } \\
\text { transactions. }\end{array}$ \\
\hline & Q30 & $\begin{array}{l}\text { The government departments ensure that employees have the knowledge } \\
\text { to answer citizens' questions. }\end{array}$ \\
\hline & Q31 & $\begin{array}{l}\text { The government departments make sure that employees give personal } \\
\text { attention to all. }\end{array}$ \\
\hline & Q32 & $\begin{array}{l}\text { The government departments make sure that employees understand } \\
\text { citizens' needs. }\end{array}$ \\
\hline & Q33 & In government departments, new ideas are readily accepted. \\
\hline & Q34 & $\begin{array}{l}\text { In government departments, management is quick to spot the need to do } \\
\text { things differently. }\end{array}$ \\
\hline TRANSF & Q35 & $\begin{array}{l}\text { In government departments, the response is quick when changes need to } \\
\text { be made. }\end{array}$ \\
\hline & Q36 & $\begin{array}{l}\text { In government departments, there is flexibility; they can quickly change } \\
\text { procedures to meet new conditions and solve problems as they arise. }\end{array}$ \\
\hline & Q37 & $\begin{array}{l}\text { In government departments, assistance in developing new ideas is readily } \\
\text { available. }\end{array}$ \\
\hline & Q38 & $\begin{array}{l}\text { The performance of e-government services related to finding information } \\
\text { is excellent. }\end{array}$ \\
\hline PERFO & Q39 & $\begin{array}{l}\text { The performance of e-government services related to completing } \\
\text { transactions is efficient. }\end{array}$ \\
\hline PERFO & Q40 & $\begin{array}{l}\text { The performance related to electronic public participation is noticeable } \\
\text { and visible. }\end{array}$ \\
\hline & Q41 & $\begin{array}{l}\text { The overall performance of e-government services is effective and } \\
\text { efficient. }\end{array}$ \\
\hline & Q42 & $\begin{array}{l}\text { I was satisfied with my experience when using e-government services } \\
\text { while looking for the information I needed. }\end{array}$ \\
\hline SATISE & Q43 & $\begin{array}{l}\text { I was satisfied with my experience while completing my e-government } \\
\text { services transactions. }\end{array}$ \\
\hline SATISF & Q44 & I was satisfied with the extent of my electronic participation as a citizen. \\
\hline & Q45 & $\begin{array}{l}\text { I was satisfied with the extent of e-government services provided through } \\
\text { multiple channels. }\end{array}$ \\
\hline & Q46 & Overall, I was satisfied with the services provided electronically. \\
\hline & Q47 & I feel that government acts in the citizens' best interest. \\
\hline TRU COF & Q48 & $\begin{array}{l}\text { I feel fine interacting with the government, since the government } \\
\text { generally fulfills its duties efficiently. }\end{array}$ \\
\hline TRU_COF & Q49 & I am comfortable relying on the government to meet their obligations. \\
\hline & Q50 & $\begin{array}{l}\text { I always feel confident that I can rely on the government to do their part } \\
\text { when I interact with them. }\end{array}$ \\
\hline
\end{tabular}




\section{Appendix 3 - Mediation Effects}

Standardized Regression Weights

\begin{tabular}{|c|c|c|c|c|}
\hline \multicolumn{3}{|c|}{ Relationship } & Estimate & $\mathrm{P}$ \\
\hline EGOV & $\rightarrow$ & TRANSF & -0.140 & $* * *$ \\
\hline TECH & $\rightarrow$ & TRANSF & -0.694 & $* * *$ \\
\hline EXPEC & $\rightarrow$ & TRANSF & 0.323 & $* * *$ \\
\hline TRANSPY & $\rightarrow$ & TRANSF & 0.154 & $* * *$ \\
\hline ACCOUNT & $\rightarrow$ & TRANSF & 0.605 & $* * *$ \\
\hline TRANSF & $\rightarrow$ & PERFO & 0.957 & $* * *$ \\
\hline PERFO & $\rightarrow$ & SATISF & 0.996 & $* * *$ \\
\hline SATISF & $\rightarrow$ & TRU_COF & 0.963 & $* * *$ \\
\hline TRANSF & $\rightarrow$ & TRU_COF & 0.918 & $* * *$ \\
\hline PERFO & $\rightarrow$ & TRU_COF & 0.959 & $* * *$ \\
\hline
\end{tabular}

Note: $* p<0.05, * * p<0.01, * * * p<0.001$ 